University of Wollongong

Research Online

Australian Institute for Innovative Materials -

Papers

Australian Institute for Innovative Materials

2012

Boron-nitrogen-hydrogen (BNH) compounds: recent developments in hydrogen storage, applications in hydrogenation and catalysis, and new syntheses

Zhenguo Huang

University of Wollongong, zhenguo@uow.edu.au

Tom Autrey

Pacific Northwest National Laboratories, tom.autrey@pnnl.gov

Follow this and additional works at: https://ro.uow.edu.au/aiimpapers

Part of the Engineering Commons, and the Physical Sciences and Mathematics Commons

Research Online is the open access institutional repository for the University of Wollongong. For further information contact the UOW Library: research-pubs@uow.edu.au 


\title{
Boron-nitrogen-hydrogen (BNH) compounds: recent developments in hydrogen storage, applications in hydrogenation and catalysis, and new syntheses
}

\author{
Abstract \\ The strong efforts devoted to the exploration of BNH compounds for hydrogen storage have led to \\ impressive advances in the field of boron chemistry. This review summarizes progress in this field from \\ three aspects. It starts with the most recent developments in using $\mathrm{BNH}$ compounds for hydrogen \\ storage, covering $\mathrm{NH}_{3} \mathrm{BH}_{3}, \mathrm{~B}_{3} \mathrm{H}_{8}$ - containing compounds, and $\mathrm{CBN}$ compounds. The following section \\ then highlights interesting applications of $\mathrm{BNH}$ compounds in hydrogenation and catalysis. The last part \\ is focused on breakthroughs in the syntheses and discovery of new BNH organic analogues. The role of \\ $\mathrm{N}-\mathrm{H}^{\delta{ }_{\star} \star \star \star} \mathrm{H}^{\delta-}-\mathrm{B}$ dihydrogen interactions in molecule packing, thermal hydrogen evolution, and syntheses is \\ also discussed within the review.

\section{Keywords} \\ hydrogenation, applications, storage, developments, nitrogen, recent, hydrogen, boron, compounds, \\ catalysis, bnh, syntheses \\ Disciplines \\ Engineering | Physical Sciences and Mathematics

\section{Publication Details} \\ Huang, Z \& Autrey, T (2012), Boron-nitrogen-hydrogen (BNH) compounds: recent developments in \\ hydrogen storage, applications in hydrogenation and catalysis, and new syntheses, Energy and \\ Environmental Science, 5(11), pp. 9257-9268.
}




\title{
Boron-nitrogen-hydrogen (BNH) compounds: recent developments in hydrogen storage, applications in hydrogenation and catalysis, and new syntheses
}

\author{
Zhenguo Huang ${ }^{* a}$ and Tom Autrey ${ }^{* b}$ \\ ${ }_{5}$ Received (in $\left.X X X, X X X\right) X$ th $X X X X X X X X X 20 X X$, Accepted Xth $X X X X X X X X X 20 X X$ \\ DOI: $10.1039 / b 000000 x$
}

The strong efforts devoted to the exploration of BNH compounds for hydrogen storage have led to impressive advances in the field of boron chemistry. This review summarizes progress in this field from three aspects. It starts with the most recent developments in using BNH compounds for hydrogen storage, 10 covering $\mathrm{NH}_{3} \mathrm{BH}_{3}, \mathrm{~B}_{3} \mathrm{H}_{8}{ }^{-}$containing compounds, and CBN compounds. The following section then highlights interesting applications of BNH compounds in hydrogenation and catalysis. The last part is focused on breakthroughs in the syntheses and discovery of new BNH organic analogues. The role of $\mathrm{N}-\mathrm{H}^{\delta+} \cdots \mathrm{H}^{\delta-}-\mathrm{B}$ dihydrogen interactions in molecule packing, thermal hydrogen evolution, and syntheses is also discussed within the review.

\section{1. Introduction}

Boranes and boron-nitrogen-hydrogen (denoted as $\mathrm{BNH}$ in this review) compounds attracted intense study in the 1950s, almost exclusively for military applications. ${ }^{1,2}$ Although the goal of using these compounds as high energy fuels for jets was never 20 achieved, the concerted effort did result in a wealth of technical information on boron chemistry. ${ }^{3-8}$ Half a century of dormancy then followed, with only scattered research carried out. Most recently, $\mathrm{BNH}$ compounds have regained intense attention due to

${ }_{25}{ }^{a}$ Institute for Superconducting and Electronic Materials, University of Wollongong, Innovation Campus, Squires Way, North Wollongong, NSW, 2522, Australia. Fax: 61024221 5731; Tel: 61024221 3220, E-mail: zhenguo@uow.edu.au

${ }^{b}$ Fundamental and Computational Sciences Directorate, Pacific

30 Northwest National Laboratory, 908 Battelle Blvd K2-5, Richland, Washington 99352, USA. Fax: +01 (509) 375-3792; Tel: +01 (509) 3753792.E-mail: tom.autrey@pnnl.gov. their potential application as hydrogen storage materials. ${ }^{9-18}$ Among these compounds, ammonia borane (AB) has been 35 studied the most, since it 1 ) has a high hydrogen content of 19.4 $\mathrm{wt} \%$ and 2 ) releases $12 \mathrm{wt} \%$ hydrogen at moderate temperatures $\left(<120{ }^{\circ} \mathrm{C}\right) .{ }^{19-21} \mathrm{AB}$ is arguably one of the most promising candidates to meet many of the criteria set by the U.S. Department of Energy (DOE) for automotive applications. ${ }^{22}$

40 Two main DOE criteria relate to gravimetric and volumetric densities (Table 1$).^{23}$ These numbers refer to the whole system, including the container, heater, piping, materials, etc. Therefore, a compound with $5.5 \mathrm{wt} \%$ hydrogen fails to meet the 2017 target. There are other critical parameters, such as stability at high 45 temperatures under long dormancy and sufficient kinetics within appropriate temperature and pressure ranges. One of the challenges is to have a hydrogen storage material that can release $\mathrm{H}_{2}$ efficiently using the waste heat from a proton exchange membrane (PEM) fuel cell, $\sim 80{ }^{\circ} \mathrm{C}$, and simultaneously is

\section{Broader context}

Hydrogen is believed to be an ideal synthetic fuel for the future. It can be a highly effective medium to store and transfer energy produced by renewable resources such as wind and solar, whose intermittent nature has limited their wide deployment. Its chemical energy can be extracted using a fuel cell to power an electrical engine at very high efficiency, and this process produces virtually no pollution. One key technological challenge for the transformation to hydrogen-based energy is to find a safe and efficient way to store hydrogen. A hydrogen storage system for both stationary and mobile applications must possess a number of characteristics, such as high storage capacity, fast kinetics, long cycle life, and safety under normal use. Solid state hydrogen storage has attracted substantial research and development around the world, since it offers higher volumetric and gravimetric capacities than traditional compression and liquefaction. Intense efforts have been directed towards research on boron-nitrogen-hydrogen (BNH) compounds, among which, ammonia borane is the outstanding example. The strong investment in BNH by government agencies, universities, and companies has led to a much improved understanding of boron chemistry, which provides essential guidance in the search for ideal hydrogen storage candidates, as well as interesting applications in other fields. 
indefinitely stable at $60^{\circ} \mathrm{C}$. This represents an enormous change in reactivity over a narrow temperature range, i.e., $0 \mathrm{~g} \mathrm{H}_{2}$ /s below $60{ }^{\circ} \mathrm{C}$ and $>1 \mathrm{~g} \mathrm{H}_{2} / \mathrm{s}$ at $80{ }^{\circ} \mathrm{C}^{24}$ To make $\mathrm{AB}$ suitable for practical applications, it is not necessary to destabilize it to afford 5 a faster rate at $80{ }^{\circ} \mathrm{C}$, but it is necessary to maintain control of thermal management of the exothermic reaction to keep the temperature from going too high. Therefore, approaches to enhance stability at $60{ }^{\circ} \mathrm{C}$ are much more important than approaches to destabilize $\mathrm{AB}$ to get faster rates at $80^{\circ} \mathrm{C} .^{25}$

10 As with any strong effort devoted to a certain field, the research carried out by national laboratories, academic institutions and their industry partners around the world has further enriched the field of boron chemistry. This includes, but is not limited to, a much improved understanding of reaction 15 mechanisms, ${ }^{26-29}$ promising new applications, ${ }^{30-33}$ and the discovery of new BNH compounds. ${ }^{34-36}$ Several excellent reviews on $\mathrm{BNH}$ compounds have been published with a focus on hydrogen storage. ${ }^{37-40}$ In contrast with these surveys, the present review highlights not only the most recent progress (largely from 202010 onwards) in hydrogen storage, but also includes studies of catalysis and reduction reactions (i.e. hydrogenation) and syntheses of new BNH compounds. This work is accordingly broken down into these areas, with an emphasis on important breakthroughs that may provide guidance for further research.

25 In $\mathrm{BNH}$ compounds, the $\mathrm{H}$ bound to the more electronegative $\mathrm{N}$ is protic and the $\mathrm{H}$ bound to the less electronegative $\mathrm{B}$ is hydridic. ${ }^{41-43}$ These two types of $\mathrm{H}$ atoms are commonly found to form a special interaction, i.e., $\mathrm{N}-\mathrm{H}^{\delta+} \cdots \mathrm{H}^{\delta-} \mathrm{B}$, defined as the "dihydrogen bond” by Richardon, Gala, and Crabtree, ${ }^{43}$ a term 30 which is widely used these days in most of the literature. ${ }^{44-47}$ As will be seen from this present review, the dihydrogen interaction plays an important role in molecule packing in crystals and $\mathrm{H}_{2}$ evolution. Several chemical reactions have been designed and carried out successfully based on this unique interaction.

\section{${ }_{35}$ 2. Hydrogen storage}

This section summarizes the latest developments in this field, focusing on $\mathrm{AB}$, alkali metal aminoboranes, diammoniate of diborane $\left(\left[\left(\mathrm{NH}_{3}\right)_{2} \mathrm{BH}_{2}\right]\left[\mathrm{BH}_{4}\right]\right)$ (DADB), and octahydrotriborates $\left(\mathrm{B}_{3} \mathrm{H}_{8}{ }^{-}\right)$, as well as $\mathrm{C}, \mathrm{B}$, and $\mathrm{N}$ containing compounds (denoted 40 as $\mathrm{CBN}$ in this review), such as ethane 1,2-di-amineborane $\left(\mathrm{BH}_{3} \mathrm{NH}_{2} \mathrm{CH}_{2} \mathrm{CH}_{2} \mathrm{NH}_{2} \mathrm{BH}_{3}\right)(\mathrm{EDAB})$ and $\mathrm{CBN}$ heterocycles.

\section{$2.1 \mathrm{AB}$}

\subsubsection{Hydrogen evolution pathways}

Several means have been regularly employed to extract $\mathrm{H}_{2}$ from ${ }_{45} \mathrm{AB}$, i.e., hydrolysis, ${ }^{48-50}$ solid state thermal decomposition with/without the aid of additives and metal catalysts, ${ }^{51-54}$ decomposition of $\mathrm{AB}$ in liquids with $^{55-58}$ or without catalysts, ${ }^{59,60,28}$ and more recently using $\mathrm{AB}$ in pumpable slurries similar to the approach of Safe Hydrogen. ${ }^{23,61}$ Since the 50 hydrolytic reaction affords stable B-O bonds, the reformation of

Table 1 U.S. DOE Targets for Onboard Hydrogen Storage Systems for Light-Duty Vehicles. (Please refer to U.S. DOE website for detailed technical explanation ${ }^{23}$ )

\begin{tabular}{|c|c|c|c|}
\hline Storage Parameter & Units & 2017 & Ultimate \\
\hline $\begin{array}{l}\text { System Gravimetric Capacity: } \\
\text { Usable specific-energy from } \mathrm{H}_{2} \text { (net useful energy/max } \\
\text { system mass) }\end{array}$ & $\begin{array}{c}\mathrm{kWh} / \mathrm{kg} \\
\text { (kg H} / 2 / k g \text { system) }\end{array}$ & $\begin{array}{c}1.8 \\
(0.055)\end{array}$ & $\begin{array}{c}2.5 \\
(0.075)\end{array}$ \\
\hline $\begin{array}{l}\text { System Volumetric Capacity: } \\
\text { Usable energy density from } \mathrm{H}_{2} \text { (net useful energy/max } \\
\text { system volume) }\end{array}$ & $\begin{array}{c}\mathrm{kWh} / \mathrm{L} \\
\text { (kg H} / \mathrm{L} \text { system) }\end{array}$ & $\begin{array}{c}1.3 \\
(0.040)\end{array}$ & $\begin{array}{c}2.3 \\
(0.070)\end{array}$ \\
\hline $\begin{array}{l}\text { Storage System Cost: } \\
\text { • Fuel cost }\end{array}$ & $\begin{array}{c}\text { \$/kWh net } \\
\text { (\$/kg H}) \\
\text { \$/gge at pump }\end{array}$ & $\begin{array}{c}\text { TBD } \\
\text { (TBD) } \\
2-4 \\
\end{array}$ & $\begin{array}{c}\text { TBD } \\
\text { (TBD) } \\
2-4 \\
\end{array}$ \\
\hline $\begin{array}{l}\text { Durability/Operability: } \\
\text { - Operating ambient temperature } \\
\text { - Min/max delivery temperature } \\
\text { - Operational cycle life ( } 1 / 4 \text { tank to full) } \\
\text { - Min delivery pressure from storage system; FC= fuel } \\
\text { cell, ICE= internal combustion engine } \\
\text { - Max delivery pressure from storage system } \\
\text { - Onboard efficiency } \\
\text { - "Well” to powerplant efficiency }\end{array}$ & $\begin{array}{c}{ }^{\circ} \mathrm{C} \\
{ }^{\circ} \mathrm{C} \\
\text { cycles } \\
\text { bar (abs) } \\
\text { bar (abs) } \\
\% \\
\% \\
\end{array}$ & $\begin{array}{c}-40 / 60 \text { (sun) } \\
-40 / 85 \\
1500 \\
5 \text { FC/35 ICE } \\
12 \mathrm{FC} / 100 \mathrm{ICE} \\
90 \\
60 \\
\end{array}$ & $\begin{array}{l}-40 / 60 \text { (sun) } \\
-40 / 85 \\
1500 \\
3 \text { FC/35 ICE } \\
12 \text { FC/100 ICE } \\
90 \\
60 \\
\end{array}$ \\
\hline $\begin{array}{l}\text { Charging / Discharging Rates: } \\
\text { - System fill time }(5 \mathrm{~kg}) \\
\text { - Minimum full flow rate } \\
\text { - Start time to full flow }\left(20^{\circ} \mathrm{C}\right) \\
\text { - Start time to full flow }\left(-20^{\circ} \mathrm{C}\right) \\
\text { - Transient response } 10 \%-90 \% \text { and } 90 \%-0 \% \\
\end{array}$ & $\begin{array}{l}\min _{(\mathrm{kg} \mathrm{H} / \mathrm{min})} \\
(\mathrm{g} / \mathrm{s}) / \mathrm{kW} \\
\mathrm{s} \\
\mathrm{s} \\
\mathrm{s}\end{array}$ & $\begin{array}{c}3.3 \\
(1.5) \\
0.02 \\
5 \\
15 \\
0.75 \\
\end{array}$ & $\begin{array}{c}2.5 \\
(2.0) \\
0.02 \\
5 \\
15 \\
0.75 \\
\end{array}$ \\
\hline Fuel Purity ( $\mathrm{H}_{2}$ from storage) & $\% \mathrm{H}_{2}$ & \multicolumn{2}{|c|}{$\begin{array}{c}\text { SAE J2719 and ISO/PDTS 14687-2 } \\
\text { (99.97\% dry basis) }\end{array}$} \\
\hline $\begin{array}{l}\text { Environmental Health \& Safety: } \\
\text { - Permeation \& leakage } \\
\text { - Toxicity } \\
\text { - Safety } \\
\text { - Loss of useable } \mathrm{H}_{2} \\
\end{array}$ & $\begin{array}{c}\mathrm{Scc} / \mathrm{h} \\
- \\
- \\
\text { (g/h) } \mathrm{kg} \mathrm{H}_{2} \text { stored } \\
\end{array}$ & \multicolumn{2}{|c|}{ Meets or exceeds applicable standards } \\
\hline
\end{tabular}


$\mathrm{AB}$ is highly energy intensive and consequently an economic challenge. Solid state thermal decomposition is believed to proceed via the intermediate $\mathrm{DADB}$ and finally results in polymeric $\mathrm{BNH}$ compounds. ${ }^{26}$ Decomposition of $\mathrm{AB}$ in ionic 5 liquid (IL) follows the same pathway, but often with significantly enhanced rates most likely as a result of enhanced heat transfer and the stabilization of DADB in ionic liquids. ${ }^{59}$

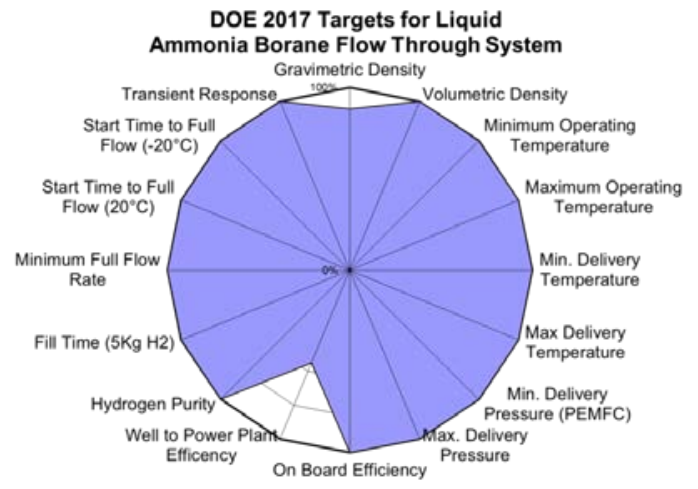

Fig. 1 Projections for exothermic AB release systems with 50\% mass loaded fluids. Reprinted from 2012 U.S. DOE Annual Review. ${ }^{62}$

$\mathrm{AB}$ decomposition in organic solvents has not yet been well studied, but recent work by Mertens' group identified interesting 10 concentration dependent dehydrogenation behavior. ${ }^{60}$ DADB influences the rates of several dehydrogenation steps by interacting with various other intermediates. In highly concentrated solutions, a similar decomposition mechanism to that of solid $\mathrm{AB}$ was observed. Although the liquid medium adds 15 a weight penalty to the system capacity, it affords easier transport of final decomposition products compared with the solid state. A recent study by a team of researchers in the Engineering Center of Excellence has shown that the performance of $\mathrm{AB}$ slurries can meet most of the U.S. DOE 2017 criteria (Fig. 1). ${ }^{62}$

20 Thermally induced $\mathrm{AB}$ dehydrogenation that is catalyzed by metal complexes in organic solutions tends to proceed via the formation of aminoborane $\left(\mathrm{NH}_{2} \mathrm{BH}_{2}\right)$, which oligomerizes to cyclic intermediates or undergoes dehydropolymerization to polyborazylene (Scheme 1). ${ }^{58,63,64}$ In addition to noble metals, ${ }^{65-}$ ${ }_{25}{ }^{67,57}$ cost effective transition metal based catalysts have also proved very effective. ${ }^{55,68}$ There exists a great variety of transition metal complexes and thus plenty of room for exploration and potential improvement with respect to efficacy and cost.

30 Thermal decomposition of neat $\mathrm{AB}$ suffers from the formation of traces of undesirable volatile products such as ammonia $\left(\mathrm{NH}_{3}\right)$ and borazine $\left(\mathrm{B}_{3} \mathrm{~N}_{3} \mathrm{H}_{6}\right){ }^{69-71}$ Many methods have been employed

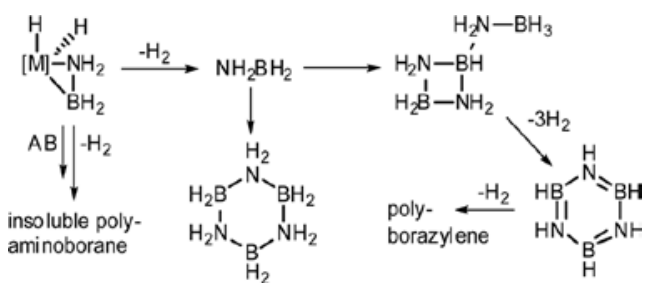

Scheme 1 Proposed metal-catalyzed reaction pathways for $\mathrm{AB}$ dehydrogenation. ${ }^{58}$ to suppress the formation of these impurities, such as the introduction of metal catalysts ${ }^{72-74}$ and additives. ${ }^{53,54,75}$ Among 35 these efforts, metal amidoboranes (MAB), such as $\mathrm{Li} / \mathrm{Na} / \mathrm{KNH}_{2} \mathrm{BH}_{3}$ and $\mathrm{Ca}\left(\mathrm{NH}_{2} \mathrm{BH}_{3}\right)_{2}$, have shown improved hydrogen release performance in terms of purity and kinetics, and therefore have attracted broad attention. ${ }^{76-80}$ Autrey's group found that $\mathrm{H}_{2}$ release from $\mathrm{MAB}$ compounds proceeds through a 40 bimolecular mechanism involving $\mathrm{MH}(\mathrm{M}=\mathrm{Li}$, $\mathrm{Na}$, or $\mathrm{K})$ compounds as intermediates. ${ }^{81}$ The decomposition products resulting from the release of 1 equivalent of $\mathrm{H}_{2}$ from these MAB compounds indicate the presence of both $\mathrm{BH}_{3}$ and $s p^{2}$ hybridized $\mathrm{BH}$ groups, which are significantly different from the products 45 formed after $\mathrm{H}_{2}$ release from AB. Theoretical work by Kim et al., ${ }^{82}$ and Lee and $\mathrm{McKee}^{83}$ demonstrates a similar role for metals in facilitating the formation of $\mathrm{H}_{2}$ by forming metal hydride intermediates during the decomposition. Recently, McGrady's group revealed new homopolar $\mathrm{H} \cdots \mathrm{H}$ interactions: viz. $\mathrm{B}-\mathrm{H}^{\delta-} \ldots{ }^{\delta-}$ $50 \mathrm{H}-\mathrm{B}$ and $\mathrm{N}-\mathrm{H}^{\delta+} \ldots{ }^{\delta+} \mathrm{H}-\mathrm{N}$, in addition to $\mathrm{M}^{\delta+} \ldots{ }^{\delta-} \mathrm{H}-\mathrm{B}$ and $\mathrm{N}-$ $\mathrm{H}^{\delta+} \ldots{ }^{\delta-} \mathrm{H}-\mathrm{B}$ interactions (Fig. 2). ${ }^{84}$ Upon heating, isotopomer $\mathrm{LiND}_{2} \mathrm{BH}_{3}$ gives off a significant quantity of $\mathrm{H}_{2}$ along with $\mathrm{HD}$, which can only arise from hydride-hydride interactions, either directly from $\mathrm{B}-\mathrm{H}^{\delta-} \ldots{ }^{\delta-} \mathrm{H}-\mathrm{B}$ moieties or indirectly through the 55 participation of $\mathrm{Li}-\mathrm{H}$ intermediates. This finding indicates that the whole $\mathrm{H}_{2}$ evolution process can be complex and can involve more than $\mathrm{N}-\mathrm{H}^{\delta+} \ldots{ }^{\delta} \mathrm{H}-\mathrm{B}$ interactions alone.

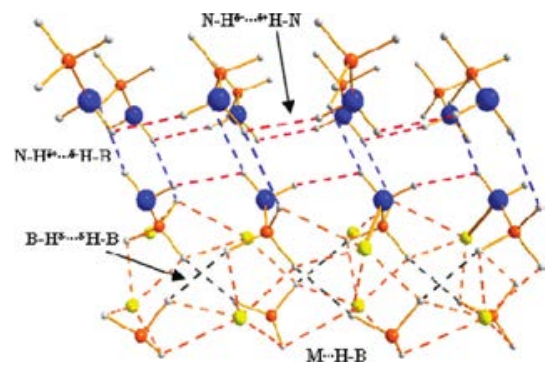

Fig. 2 Representation of the interactions in the extended structure of $\mathrm{Li} / \mathrm{NaNH}_{2} \mathrm{BH}_{3}\left(\mathrm{M}^{\delta+} \ldots{ }^{\delta-} \mathrm{H}-\mathrm{B}\right.$ : orange, $\mathrm{N}-\mathrm{H}^{\delta+} \ldots{ }^{\delta-} \mathrm{H}-\mathrm{B}$ : blue, B$\mathrm{H}^{\delta-} \ldots{ }^{\delta-} \mathrm{H}-\mathrm{B}$ : black, and $\mathrm{N}-\mathrm{H}^{\delta+} \ldots{ }^{\delta+} \mathrm{H}-\mathrm{N}$ : red dashed lines, respectively). Reprinted with permission from Ref. 84. Copyright (2011) American Chemical Society.

\section{2.1.2 Regeneration of $\mathbf{A B}$}

To make $\mathrm{AB}$ a practical storage medium for large scale applications, its efficient and economic regeneration from spent fuel is critical. The spent fuel is believed to be a mixture of polyaminoborane (PAB) and polyiminoborane (PIB), with a 65 general formulation that can be expressed as " $\mathrm{BNH}_{\mathrm{x}}$ ", with $\mathrm{x}$ varying between 0.5 and $1 .^{85}$

Early efforts devoted to the regeneration of $\mathrm{AB}$ have been summarized. ${ }^{39}$ These earlier efforts have demonstrated that the regeneration of $\mathrm{AB}$ is possible, but with high complexity and 70 cost, and low efficiency. ${ }^{86,87}$ It is known that the transition metals $\mathrm{Rh}$, Co, and Ni can be used to activate molecular hydrogen to metal hydrides at moderate temperature and pressure. $^{88} \mathrm{~A}$ concerted effort was made to find metal hydrides with sufficient hydride donor ability to transfer a hydride to a borate ester that 75 could be generated in the digestion of spent BNH fuels with a range of alcohols. This approach used a combination of 
experiment and theory to match the $\mathrm{H}^{-}$affinity of the borate ester with the $\mathrm{H}^{-}$donor capability of the metal hydride to maximize efficiency and minimize energy steps. ${ }^{89,90}$

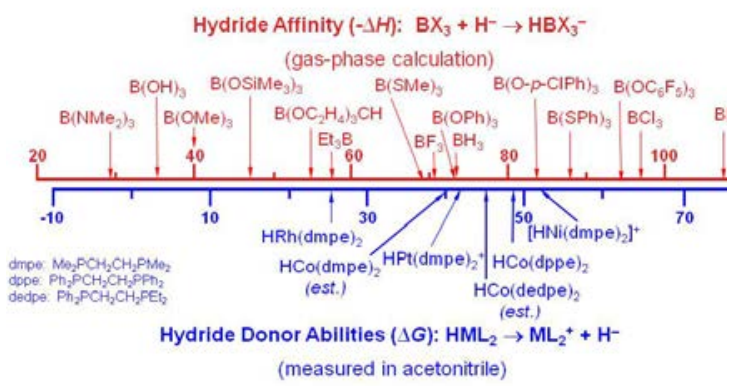

Fig. 3 Scales of experimentally determined hydride donor capabilities of selected transition-metal hydride complexes in acetonitrile (blue, bottom) and the calculated gas-phase hydride affinity values for selected $\mathrm{BX}_{3}$ compounds (red, top). Reprinted with permission from Ref. 89. Copyright (2009) American Chemical Society.

$5 \quad$ Fig. 3 shows that not all borate esters are the same, and there is a wide range of $\mathrm{H}^{-}$affinity, depending on the structural and electronic properties of the borate ester. An important outcome of this work was to show that borate esters are not a thermodynamic dead end: in fact, there are a range of borate esters that can be 10 reduced by metal hydrides. On a parallel scale, Fig. 3 shows that the hydride donating capability of the metal hydride can be tuned by changing either the metal or the ligands attached to the metal.

\section{Step 1: Digestion \\ $\mathrm{BNH}_{\mathrm{n}}+3 \mathrm{HX} \rightarrow{ }^{\mathrm{n}} / 2 \mathrm{H}_{2} \uparrow+\mathrm{NH}_{3} \uparrow+\mathrm{BX}_{3}$}

Step 2: Transition Metal Hydride Formation

$3 \mathrm{M}^{+}+3 \mathrm{H}_{2} \rightarrow 3 \mathrm{MH}_{2}^{+}[+3$ base $] \rightarrow 3 \mathrm{MH}+3 \mathrm{H}^{+}$base

Step 3: Hydride Transfer/Ligand Redistribution

$3 \mathrm{MH}+4 \mathrm{BX}_{3}+\mathrm{Et}_{3} \mathrm{~N} \rightarrow 3 \mathrm{M}^{+}+3 \mathrm{BX}_{4}^{-}+\mathrm{Et}_{3} \mathrm{NBH}_{3}$

\section{Step 4: Recycling}

$3 \mathrm{BX}_{4}^{-}+3 \mathrm{H}^{+}$base $\rightleftharpoons 3 \mathrm{HX} \uparrow+3$ base $+2 \mathrm{BX}_{3}$

\section{Step 5: Ammoniation}

$\mathrm{Et}_{3} \mathrm{NBH}_{3}+\mathrm{NH}_{3} \rightarrow \mathrm{BH}_{3} \mathrm{NH}_{3} \downarrow+\mathrm{Et}_{3} \mathrm{~N}$

Scheme 2 The 5 key steps of an overall process that regenerates $\mathrm{AB}$ from $\mathrm{H}_{2}$ with recycling of other reagents and solvent. ${ }^{91}$

15 Scheme 2 shows the 5 key steps of an overall process that regenerates $\mathrm{AB}$ from $\mathrm{H}_{2}$ with recycling of other reagents and the solvent. Each step of the process has been studied in detail to gain insight into the factors that affect reactivity and efficiency. ${ }^{92}$ While each key step has been demonstrated, further work is 20 needed to optimize the process and make the activation of hydrogen catalytic.

Very recently, a surprising, and efficient one pot regeneration method has been reported. ${ }^{93}$ In all previous cases, metal hydrides 25 were used to regenerate the hydridic B-H bonds, however, in this new method, anhydrous hydrazine, not typically considered to provide hydridic hydrogen, almost completely converts polyborazylene back to $A B$ via treatment with hydrazine $\left(\mathrm{N}_{2} \mathrm{H}_{4}\right)$ in liquid $\mathrm{NH}_{3}$ at $40{ }^{\circ} \mathrm{C}$ in a sealed pressure vessel. This process 30 involves neither noble metal nor transition metal catalysts, and while the mechanism of $\mathrm{B}-\mathrm{H}$ bond formation is not understood the process is simple and efficient (up to 95\% yield). Fig. 4 illustrates the closed cycle for the usage and reformation of AB. Hydrazine, however, is in limited production worldwide. Large35 scale economical production is thus needed to make this method a practical industrial process.

The optimum regeneration process for $\mathrm{BNH}$ hydrogen storage materials will require catalysts to activate hydrogen, e.g., to make hydrazine from nitrogen or boranes form borates. Using any 40 material besides hydrogen, a metal hydride or hydrazine in stoichiometric amounts will be very difficult to accomplish economically at large scales.

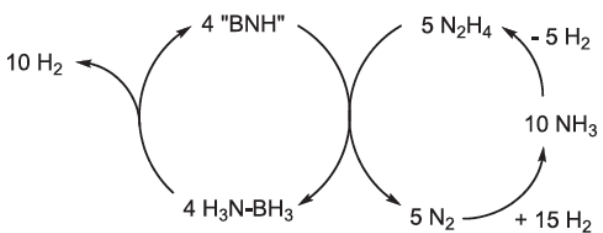

Fig. 4 Ideal overall reaction scheme for $A B$ regeneration with hydrazine. Reprinted with permission from Ref. 93. Copyright (2011) The American Association for the Advancement of Science.

45

\subsection{Diammoniate of diborane (DADB)}

In contrast to the intensive attention devoted to $\mathrm{AB}$ as a potential hydrogen storage material, much less is known about the isomer, DADB, in spite of its discovery predating that of $\mathrm{AB} .{ }^{94,95} \mathrm{DADB}$ 50 has been experimentally proven to be an intermediate during the thermal decomposition of $\mathrm{AB}$ and $\mathrm{AB} / \mathrm{IL}$ blends, ${ }^{26,58}$ but its synthesis and isolation have always been challenging until very recently. Here, we summarize the most recent progress on this compound, with a focus on its preparation.

55 The earlier syntheses of DADB used direct reaction of $\mathrm{B}_{2} \mathrm{H}_{6}$ and $\mathrm{NH}_{3}$ at cryogenic temperatures. ${ }^{96,97}$ These methods, however, do not afford high purity. In addition, $\mathrm{B}_{2} \mathrm{H}_{6}$ is highly flammable and thus very difficult to handle. Autrey's group recently developed a solid state synthesis of $\mathrm{DADB}$ by reacting 60 ammonium borohydride $\left(\mathrm{NH}_{4} \mathrm{BH}_{4}\right)$ with $\mathrm{AB} .{ }^{98} \mathrm{NH}_{4} \mathrm{BH}_{4}$ was first synthesized by reacting $\mathrm{NH}_{4} \mathrm{~F}$ and $\mathrm{NaBH}_{4}$ in liquid $\mathrm{NH}_{3}$ at -78 ${ }^{\circ} \mathrm{C}$. After a 1:1 molar mixture of $\mathrm{AB}$ and $\mathrm{NH}_{4} \mathrm{BH}_{4}$ was mechanically mixed in a SPEX mill for 10 minutes, phase pure DADB was obtained. The reaction mechanism can be expressed 65 as:

$\mathrm{NH}_{4} \mathrm{BH}_{4}+\mathrm{NH}_{3} \mathrm{BH}_{3} \rightarrow\left[\left(\mathrm{NH}_{3}\right)_{2} \mathrm{BH}_{2}\right]\left[\mathrm{BH}_{4}\right]+\mathrm{H}_{2}$

The authors solved the crystal structure of DADB from a combination of X-ray and neutron powder diffraction analysis using Rietveld refinement. There are two crystallographically 70 distinct $\mathrm{BH}_{4}^{-}$sites which coordinate with neighbouring $\left(\mathrm{NH}_{3}\right)_{2} \mathrm{BH}_{2}^{+}$ions in different ways (Fig. 5). The nearest $\mathrm{N}-$ 
$\mathrm{H}^{\delta+} \ldots{ }^{\delta+} \mathrm{H}-\mathrm{N}$ distances range from 1.8 to $2.1 \AA$, indicating the presence of dihydrogen interactions.

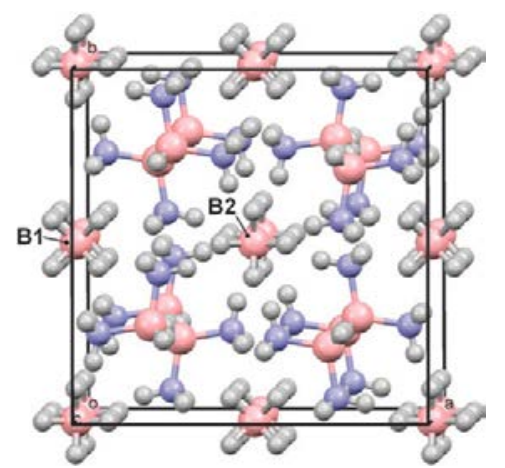

Fig. 5 Crystal structure of DADB viewed along the caxis. The two crystallographically distinct $\mathrm{BH}_{4}{ }^{-}$sites are indicated. ${ }^{98}$

5 A modified synthetic route has been developed by Fang et al. ${ }^{99}$ Instead of isolating pure $\mathrm{NH}_{4} \mathrm{BH}_{4}$, they ball milled $\mathrm{NaBH}_{4}$ together with $\mathrm{NH}_{4} \mathrm{~F}$ using a low energy Fritsch 7 planetary mill. The X-ray diffraction pattern indicates the formation of DADB and $\mathrm{NaF}$. About 1 mole $\mathrm{H}_{2}$ per mole of $\mathrm{NaBH}_{4}$ (or $\mathrm{NH}_{4} \mathrm{~F}$ ) was 10 observed after $3 \mathrm{~h}$ milling. The reaction seems to follow the same pathways as those of Autrey's method. ${ }^{98}$ Initially, $\mathrm{NH}_{4} \mathrm{BH}_{4}$ was formed during the ball milling (Eq. (2)), and then part of it decomposed into $\mathrm{NH}_{3} \mathrm{BH}_{3}$ and $\mathrm{H}_{2}$ upon further milling (Eq. (3)). The newly formed $\mathrm{NH}_{3} \mathrm{BH}_{3}$ was then reacted with $\mathrm{NH}_{4} \mathrm{BH}_{4}$ and 15 produced DADB (Eq. (4)). This modified method simplifies manipulation of the reaction and is feasible for bench-top scale synthesis in a typical laboratory.

$$
\begin{aligned}
2 \mathrm{NaBH}_{4}+2 \mathrm{NH}_{4} \mathrm{~F} \rightarrow 2 \mathrm{NH}_{4} \mathrm{BH}_{4}+2 \mathrm{NaF} \\
{ }_{20} \mathrm{NH}_{4} \mathrm{BH}_{4} \rightarrow \mathrm{NH}_{3} \mathrm{BH}_{3}+\mathrm{H}_{2} \\
\mathrm{NH}_{4} \mathrm{BH}_{4}+\mathrm{NH}_{3} \mathrm{BH}_{3} \rightarrow \mathrm{DADB}+\mathrm{H}_{2}
\end{aligned}
$$

Another quite different method has also been developed. ${ }^{100}$ This synthesis, however, involves more steps and has a complex ${ }_{25}$ set-up associated with handling gaseous $\mathrm{HCl}$ and liquid $\mathrm{NH}_{3}$.

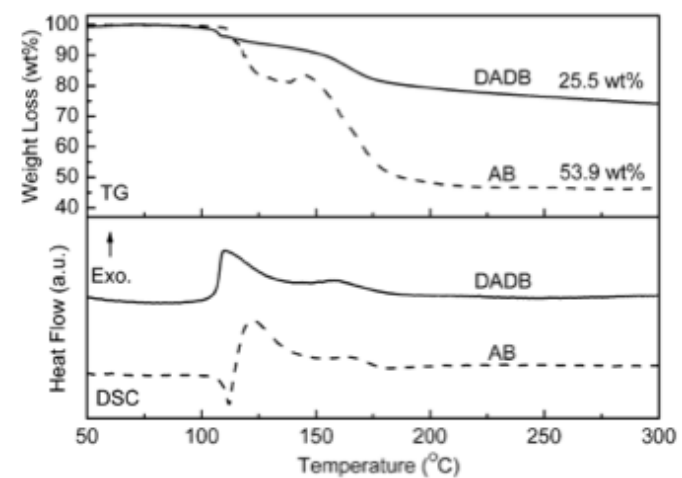

Fig. 6 Comparison of thermogravimetric analysis (TGA)/differential scanning calorimetry (DSC) profiles of DADB (solid lines) and $\mathrm{AB}$ (dashed lines). The heating rate was $5{ }^{\circ} \mathrm{C} / \mathrm{min}^{99}$

Although DADB remains stable in the solid state if stored in an inert atmosphere, it undergoes quick decomposition in solvents at room temperature with partial conversion to $\mathrm{AB} .^{100}$

Upon heating, DADB undergoes decomposition in two steps, 30 similar to those of $\mathrm{AB}$ (Fig. 6) ${ }^{99}$ The onset temperature for the first step, however, is lower for DADB than for AB. DADB exhibits no appreciable induction period, even at moderate temperatures, while $\mathrm{AB}$ suffers from a long induction period prior to $\mathrm{H}_{2}$ release. This is consistent with the finding that DADB is an 35 intermediate during the decomposition of $\mathrm{AB}$. It has also been noted that $\mathrm{AB}$ is an intermediate in the decomposition of DADB and that the mixture of the two are more reactive then either species independently. Evidence for this arises from the observation that the ${ }^{11} \mathrm{~B}$ NMR of the product, $\mathrm{PAB}$, is identical no 40 matter the starting material, ${ }^{31} \mathrm{AB}$ or $\mathrm{DADB}$, and the observation that the rate of $\mathrm{H}_{2}$ release from $\mathrm{AB}$ or DADB is identical during the 'second half-life' consistent with a similar decomposition pathway after the establishment of an equilibrium, Eq. (5) and (6) (Fig. 7). ${ }^{31}$

45
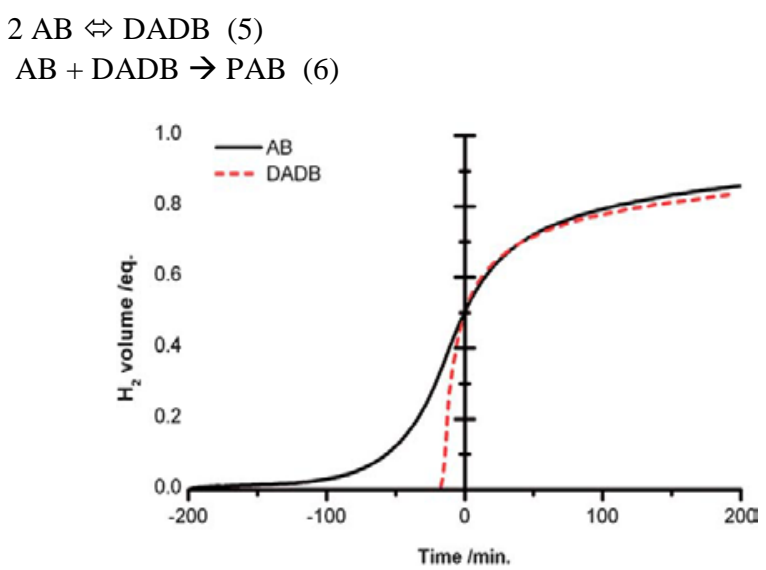

Fig. 7 Comparison of hydrogen release rates from $A B$ and DADB at $85{ }^{\circ} \mathrm{C}$ measured in a gas buret normalized for $\tau(1 / 2)=0$. Note that $\mathrm{AB}$ is slower than $\mathrm{DADB}$ in the first half-life; however, the rates are nearly equivalent for the second half-life. ${ }^{31}$

Sneddon's group has also reported the superior performance of $50 \mathrm{DADB}$ over $\mathrm{AB}$ in terms of decomposition in ionic liquid, where a faster release rate from DADB has been observed. ${ }^{59}$

\subsection{Octahydrotriborate}

There exist a variety of $\mathrm{B}_{\mathrm{m}} \mathrm{H}_{\mathrm{n}}$ moieties that are either neutral, such as $\mathrm{B}_{2} \mathrm{H}_{6}$ and $\mathrm{B}_{4} \mathrm{H}_{10}$, or carry one or two negative charges, ${ }_{55} \mathrm{BH}_{4}{ }^{-}$and $\mathrm{B}_{12} \mathrm{H}_{12}{ }^{2-}$ for instance. So far, $\mathrm{NH}_{3} \mathrm{BH}_{3}$ and $\mathrm{NaBH}_{4}$ have been intensively studied. One $\mathrm{BH}$ condensation up on the ladder from these is $\mathrm{B}_{2} \mathrm{H}_{6}$, however, its explosive and toxic nature virtually eliminates it from any significant attention. Another $\mathrm{BH}$ condensation up is $\mathrm{B}_{3} \mathrm{H}_{7}$ (best known in the form of $\mathrm{NH}_{3} \mathrm{~B}_{3} \mathrm{H}_{7}$ ) 60 and $\mathrm{B}_{3} \mathrm{H}_{8}{ }^{-}$, both of which have high hydrogen content. Sneddon's group have carried out outstanding work on $\mathrm{NH}_{3} \mathrm{~B}_{3} \mathrm{H}_{7}$, from synthesis and the structure solution to hydrogen release. ${ }^{101,102}$ Beyond these initial reports, little follow-up work on $\mathrm{NH}_{3} \mathrm{~B}_{3} \mathrm{H}_{7}$ has been done, so this review is focused on $\mathrm{B}_{3} \mathrm{H}_{8}{ }^{-}$compounds. 65

\subsection{1 $\mathrm{NH}_{4} \mathrm{~B}_{3} \mathrm{H}_{8}$}

Although $\mathrm{NaB}_{3} \mathrm{H}_{8}$ does not contain $\mathrm{N}$, it will be briefly discussed 
because of its importance as a precursor to other $\mathrm{B}_{3} \mathrm{H}_{8}{ }^{-}$ compounds. $\mathrm{NaB}_{3} \mathrm{H}_{8}$ has a higher hydrogen capacity (12.6 wt\% $\mathrm{H})$ compared with the intensively studied $\mathrm{NaBH}_{4}$ (10.8 wt\%). Historically, $\mathrm{NaB}_{3} \mathrm{H}_{8}$ was obtained in a solvated form and then 5 used as a precursor for further syntheses of other $\mathrm{B}_{3} \mathrm{H}_{8}{ }^{-} / \mathrm{B}_{3} \mathrm{H}_{7}$ compounds. ${ }^{103-108}$ From a hydrogen storage point of view, the unsolvated form of $\mathrm{NaB}_{3} \mathrm{H}_{8}$ is necessary because solvents add penalty weight. The synthesis of unsolvated $\mathrm{NaB}_{3} \mathrm{H}_{8}$, however, traditionally requires $\mathrm{B}_{2} \mathrm{H}_{6} \cdot{ }^{109,110}$ Recently, Huang et al. 10 developed a $\mathrm{B}_{2} \mathrm{H}_{6}$-free method to synthesize unsolvated $\mathrm{NaB}_{3} \mathrm{H}_{8}$ with a yield close to $70 \%{ }^{111}$ There is concern over this route, however, since mercury is used, although it can be recycled. Chong et al. have reported an alternative solvent free synthesis of $\operatorname{Mg}\left(\mathrm{B}_{3} \mathrm{H}_{8}\right)_{2}$ with about $12 \%$ yield in the thermal decomposition of ${ }_{15} \mathrm{Mg}\left(\mathrm{BH}_{4}\right)_{2}$ at $300{ }^{\circ} \mathrm{C} .{ }^{112}$ Heating at lower temperatures for longer periods of time, $250{ }^{\circ} \mathrm{C}$ for 5 weeks, did lead to higher yields however further work is required to optimize this synthetic pathway.

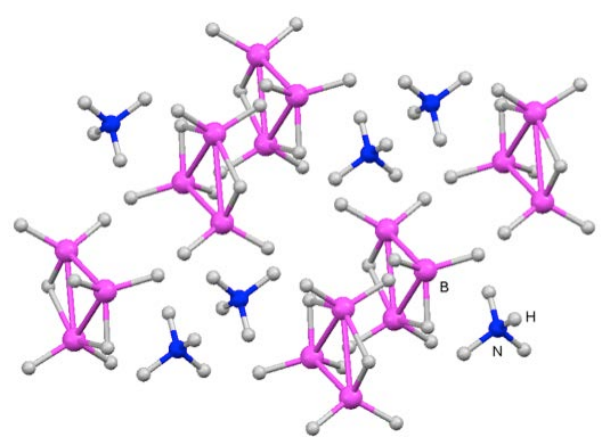

Fig. 8 Crystal structure of $\mathrm{NH}_{4} \mathrm{~B}_{3} \mathrm{H}_{8}$ : B: pink, H: light grey, N: blue. Reprinted with permission from Ref. 116. Copyright (2011) American Chemical Society.

Ammonium octahydrotriborate $\left(\mathrm{NH}_{4} \mathrm{~B}_{3} \mathrm{H}_{8}\right)$ has a very high hydrogen content of $20.5 \mathrm{wt} \%$. The original synthesis reported 40 years ago involved pentaborane $\left(\mathrm{B}_{5} \mathrm{H}_{9}\right)$, which is highly volatile and inflames violently upon contact with air. ${ }^{113,114}$ Pentaborane25 free patents were later developed, but the procedures are complicated, requiring intermediate compounds and large amounts of solvents. ${ }^{115}$ Huang et al. recently found that by reacting unsolvated $\mathrm{NaB}_{3} \mathrm{H}_{8}$ with $\mathrm{NH}_{4} \mathrm{Cl}$ in liquid $\mathrm{NH}_{3}$ at $-78{ }^{\circ} \mathrm{C}$, $\mathrm{NH}_{4} \mathrm{~B}_{3} \mathrm{H}_{8}$ was formed and could be extracted using dry 30 tetrahydrofuran (THF). ${ }^{116}$ This process can also be carried out with solvated $\mathrm{NaB}_{3} \mathrm{H}_{8}$, since 1) solvents coordinated to $\mathrm{NaB}_{3} \mathrm{H}_{8}$ will not change the course of the reaction; 2) $\mathrm{NH}_{4} \mathrm{~B}_{3} \mathrm{H}_{8}$ can be easily isolated using $\mathrm{THF}$; and 3 ) the $\mathrm{NaCl}$ side product is insoluble in most organic solvents. In this case, different 35 synthetic routes to solvated $\mathrm{NaB}_{3} \mathrm{H}_{8}$ can be employed, and thus mercury can be avoided. ${ }^{103-105}$

A separate ion pair structure exists in $\mathrm{NH}_{4} \mathrm{~B}_{3} \mathrm{H}_{8}$ (Fig. 8), with the shortest $\mathrm{N}-\mathrm{H}^{\delta+} \cdots \mathrm{H}^{\delta-}-\mathrm{B}$ distance being $2.37 \AA$, very close to the sum of the van der Waals radii between two hydrogen atoms, $402.4 \AA$. All other $\mathrm{N}-\mathrm{H}^{\delta+} \cdots \mathrm{H}^{\delta-}-\mathrm{B}$ distances are more than $2.47 \AA$. These dihydrogen distances are longer that those observed in $\mathrm{NH}_{3} \mathrm{~B}_{3} \mathrm{H}_{7}{ }^{102}$ and $\mathrm{NH}_{3} \mathrm{BH}_{3}{ }^{117}$. $\mathrm{NH}_{4} \mathrm{~B}_{3} \mathrm{H}_{8}$ in pure and solid form is stable at room temperature, with no detectable signs of decomposition within one month.

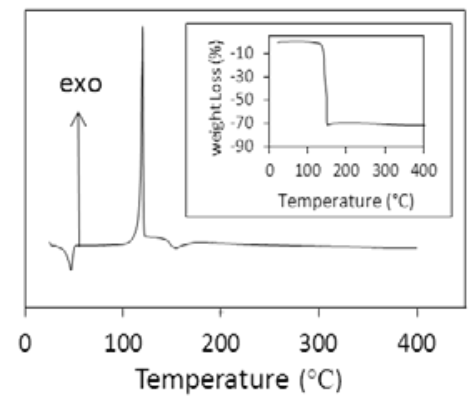

Fig. 9 DSC and TGA (inset) profiles of $\mathrm{NH}_{4} \mathrm{~B}_{3} \mathrm{H}_{8}$. The heating rate was $5{ }^{\circ} \mathrm{C} / \mathrm{min}$. Reprinted with permission from Ref. 116 . Copyright (2011) American Chemical Society.

45

DSC and TGA results collectively indicate that melting and decomposition take place simultaneously at $120{ }^{\circ} \mathrm{C}$, with a substantial weight loss at this temperature (Fig. 9). ${ }^{116}$ However, only $10 \mathrm{wt} \%$ of the weight loss is associated with $\mathrm{H}_{2}$, while the 50 rest is due to the formation of $\mathrm{B}_{2} \mathrm{H}_{6}, \mathrm{~B}_{5} \mathrm{H}_{9}$, and $\mathrm{B}_{3} \mathrm{~N}_{3} \mathrm{H}_{6}$. Thus, $\mathrm{NH}_{4} \mathrm{~B}_{3} \mathrm{H}_{8}$ is not a suitable candidate for hydrogen storage through thermal decomposition without additional work.

Hydrolytic studies, however, have demonstrated that $\mathrm{NH}_{4} \mathrm{~B}_{3} \mathrm{H}_{8}$ has advantages over $\mathrm{NaBH}_{4}$ and $\mathrm{NH}_{3} \mathrm{BH}_{3}$, the most studied 55 chemical hydrides for hydrogen storage via hydrolysis. $\mathrm{NH}_{4} \mathrm{~B}_{3} \mathrm{H}_{8}$ is more soluble in water ( $>45$ wt \%) than $\mathrm{NH}_{3} \mathrm{BH}_{3}(26 \mathrm{wt} \%)^{118}$ and $\mathrm{NaBH}_{4}$ (35 wt \%) ${ }^{119}$. The lower solubility limits the theoretical hydrogen density of the respective systems to $5.1 \mathrm{wt}$ $\%$ for $\mathrm{NH}_{3} \mathrm{BH}_{3}$ and 7.5 wt \% for $\mathrm{NaBH}_{4}$. Hydrolysis showed that

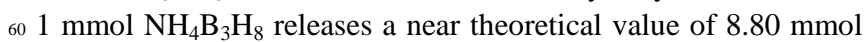
$\mathrm{H}_{2}$. Based on Eq. (7), therefore, this system has a high theoretical hydrogen weight density (wt \% $=\mathrm{H}_{2} /\left(\mathrm{NH}_{4} \mathrm{~B}_{3} \mathrm{H}_{8}+\mathrm{H}_{2} \mathrm{O}\right)$ ) of 10.8 wt \%.

$$
\underset{\mathrm{NH}_{4} \mathrm{~B}_{3} \mathrm{H}_{8}(\mathrm{~s})+6 \mathrm{H}_{2} \mathrm{O}(\mathrm{l})}{\stackrel{\text { cat. }}{\rightarrow}} \mathrm{NH}_{4}^{+}(\mathrm{aq})+3 \mathrm{BO}_{2}^{-}(\mathrm{aq})+2 \mathrm{H}^{+}(\mathrm{aq})+9 \mathrm{H}_{2}(\mathrm{~g})
$$

Unlike $\mathrm{NaBH}_{4}$, which is stable only in strong alkaline solutions, ${ }^{120,121}$ an aqueous $\mathrm{NH}_{4} \mathrm{~B}_{3} \mathrm{H}_{8}$ solution is reasonably stable. At $28{ }^{\circ} \mathrm{C}$, for the same molar concentration, i.e., $2 \mathrm{M},{ }^{11} \mathrm{~B}$ nuclear magnetic resonance (NMR) studies showed that more 70 than $50 \%$ of $\mathrm{NaBH}_{4}$ decomposed over one day, while less than $10 \%$ of $\mathrm{NH}_{4} \mathrm{~B}_{3} \mathrm{H}_{8}$ decomposed over a week. ${ }^{116}$ Calculations indicate that $\mathrm{H}_{2}$ release from $\mathrm{NH}_{4} \mathrm{~B}_{3} \mathrm{H}_{8}$ is much less exothermic than from $\mathrm{NaBH}_{4}, \mathrm{NH}_{3} \mathrm{BH}_{3}$, or $\mathrm{NH}_{3} \mathrm{~B}_{3} \mathrm{H}_{7}$. Its less exothermic nature favors $\mathrm{NH}_{4} \mathrm{~B}_{3} \mathrm{H}_{8}$ over the other candidates from the 75 standpoint of heat management and system design.

\subsubsection{Diammoniate of tetraborane $\left(\left(\mathrm{NH}_{3}\right)_{2} \mathrm{BH}_{2} \mathrm{~B}_{3} \mathrm{H}_{8}\right)$}

This compound has a high hydrogen content of $18.2 \mathrm{wt} \%$, however, the only available syntheses involve tetraborane $80\left(\mathrm{~B}_{4} \mathrm{H}_{10}\right)$, which is highly volatile and combusts violently upon contact with air. ${ }^{122,123}$ Furthermore, $\mathrm{B}_{4} \mathrm{H}_{10}$ is not commercially available, and its synthesis remains complex and challenging. ${ }^{124}$ There have been few studies on this compound since its discovery 50 years ago. Huang et al. recently developed a safe and efficient 85 synthesis method for this compound and studied its thermal decomposition properties. ${ }^{125}$ 
By utilizing two well-known reactions: $\mathrm{NH}_{3}$ reacting with THF $\cdot \mathrm{BH}_{3}$ to form DADB and $\mathrm{AB},{ }^{95,126}$ and DADB reacting with $\mathrm{NH}_{4} \mathrm{Cl}$ to produce $\left(\mathrm{NH}_{3}\right)_{2} \mathrm{BH}_{2} \mathrm{Cl},{ }^{11,127}$ Huang et al. obtained $\left(\mathrm{NH}_{3}\right)_{2} \mathrm{BH}_{2} \mathrm{~B}_{3} \mathrm{H}_{8}$ via the metathesis between $\mathrm{NaB}_{3} \mathrm{H}_{8}$ and $5\left(\mathrm{NH}_{3}\right)_{2} \mathrm{BH}_{2} \mathrm{Cl}$. This procedure avoids flammable starting materials and produces high purity products, as evidenced by the NMR spectra (Fig. 10).

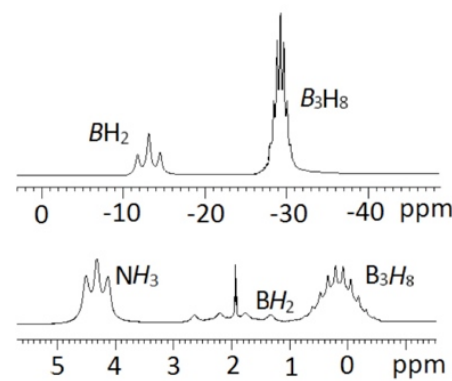

Fig. $10{ }^{11} \mathrm{~B}$ NMR spectrum of $\left(\mathrm{NH}_{3}\right)_{2} \mathrm{BH}_{2} \mathrm{~B}_{3} \mathrm{H}_{8}$ in THF (top), and ${ }^{1} \mathrm{H}$ NMR spectrum in $\mathrm{CD}_{3} \mathrm{CN}$ (bottom). ${ }^{125}$

10 The DSC and TGA results indicate that melting and decomposition take place simultaneously at $100{ }^{\circ} \mathrm{C}$ and finish at around $160{ }^{\circ} \mathrm{C}$, with a total weight loss of $40 \mathrm{wt} \%$. Approximately $15 \mathrm{wt} \%$ of the weight loss is due to $\mathrm{H}_{2}$ evolution, while the rest is associated with $\mathrm{B}_{2} \mathrm{H}_{6}, \mathrm{~B}_{5} \mathrm{H}_{9}$, and $\mathrm{B}_{3} \mathrm{~N}_{3} \mathrm{H}_{6}$.

15 It is well known that thermal decomposition of $\mathrm{B}_{3} \mathrm{H}_{8}$ containing compounds tends to generate $\mathrm{B}_{5} \mathrm{H}_{9}$ and/or $\mathrm{B}_{2} \mathrm{H}_{6}$. ${ }^{105,107}$ The presence of the protonic $\mathrm{NH}$ groups seems to suppress the formation of these boranes and facilitates the formation of $\mathrm{H}_{2}$, considering the total $70 \mathrm{wt} \%$ weight loss and the $10 \mathrm{wt} \% \mathrm{H}_{2}$ for ${ }_{20} \mathrm{NH}_{4} \mathrm{~B}_{3} \mathrm{H}_{8}\left(\mathrm{H}^{\delta+}: \mathrm{H}^{\delta-}=3: 6\right)$, compared to the total $40 \mathrm{wt} \%$ weight loss and $15 \mathrm{wt} \% \mathrm{H}_{2}$ for $\left(\mathrm{NH}_{3}\right)_{2} \mathrm{BH}_{2} \mathrm{~B}_{3} \mathrm{H}_{8}\left(\mathrm{H}^{\delta+}: \mathrm{H}^{\delta-}=3: 5\right)$.

\subsection{CBN compounds}

\subsubsection{Ethane 1,2-di-amineborane $\left(\mathrm{BH}_{3} \mathrm{NH}_{2} \mathrm{CH}_{2} \mathrm{CH}_{2} \mathrm{NH}_{2} \mathrm{BH}_{3}\right)$} (EDAB)

${ }_{25}$ EDAB has recently been studied as a promising hydrogen storage candidate (Fig. 11). ${ }^{128}$ EDAB possesses a number of distinct advantages compared with $\mathrm{AB}$. First of all, it is more stable than $\mathrm{AB}$ at temperatures lower than $100{ }^{\circ} \mathrm{C}$, indicating that storage at high temperature $\left(>60{ }^{\circ} \mathrm{C}\right)$ for a prolonged period is practical. 30 Secondly, it releases hydrogen more rapidly than $\mathrm{AB}$ at temperatures higher than $120^{\circ} \mathrm{C}$, and this means that EDAB is

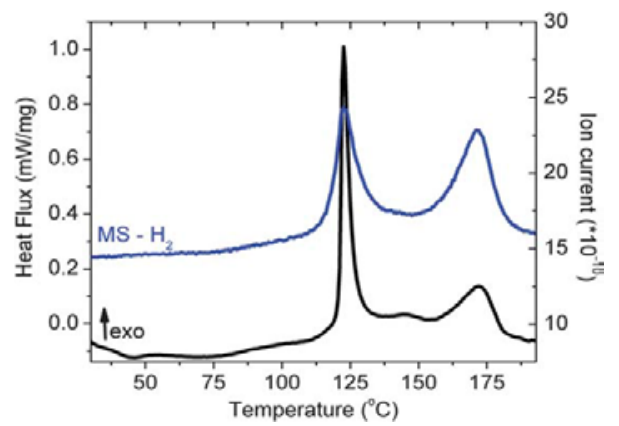

Fig. 11 DSC/mass spectroscopy (MS) data obtained by heating EDAB at $1{ }^{\circ} \mathrm{C} / \mathrm{min}$ from $25^{\circ} \mathrm{C}$ to $200{ }^{\circ} \mathrm{C}$. Black curve is the heat flux; blue curve is the MS data. ${ }^{128}$ more effective at providing $\mathrm{H}_{2}$ when needed, especially during acceleration (Fig. 12). A fast rate at the release temperatures coupled with stability at high storage temperatures is a significant 35 concern for practical storage, but this has so far been elusive for approaches aimed at enhancing the rate of hydrogen release from solid $\mathrm{AB}$. The enthalpy of $\mathrm{H}_{2}$ release is less exothermic than for $\mathrm{AB}$, amounting to approximately $-10 \mathrm{~kJ} / \mathrm{mol} \mathrm{H}_{2}$ and $-4 \mathrm{~kJ} / \mathrm{mol}$ $\mathrm{H}_{2}$ for the first and second steps, respectively, which will simplify 40 heat management in practical devices. Furthermore, there are no detectable impurities, and in particular, no $\mathrm{B}_{3} \mathrm{~N}_{3} \mathrm{H}_{6}, \mathrm{NH}_{3}$, or $\mathrm{B}_{2} \mathrm{H}_{6}$. The absence of $\mathrm{B}_{3} \mathrm{~N}_{3} \mathrm{H}_{6}$ and $\mathrm{NH}_{3}$ is not a surprise as it is difficult to provide a mechanism to show how they would be formed from EDAB, however, the absence of $\mathrm{B}_{2} \mathrm{H}_{6}$ needs further study as it is ${ }_{45}$ difficult to detect given the high reactivity.

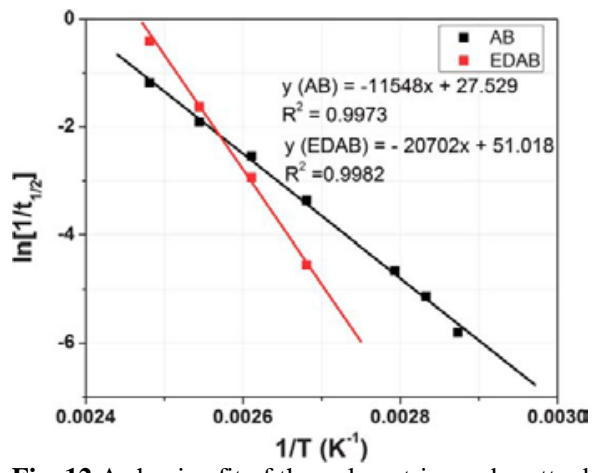

Fig. 12 Arrhenius fit of the volumetric gas burette data for $\mathrm{EDAB}$ and $\mathrm{AB} .{ }^{128}$

\subsubsection{Heterocycles}

This class of compounds (i.e., cyclic molecules containing C, B, 50 and $\mathrm{N}$ ) for hydrogen storage has recently been investigated by Liu's group from the University of Oregon. ${ }^{129-131}$ The aim of this research is to develop liquid hydrogen storage materials to make use of the existing liquid fuel distribution channels such as pipelines and tankers, which would be more cost-effective 55 compared with transporting solid hydrogen storage materials. Liu's group has carried out elaborate work on the synthesis, catalytic dehydrogenation, and regeneration of several CBN heterocycles. One sample of particular interest is $\mathrm{BN}$ methylcyclopentane (Scheme 3), ${ }^{132}$ which is in liquid form under 60 ambient conditions. Upon adding cheap catalysts such as $\mathrm{FeCl}_{2}$ and $\mathrm{NiCl}_{2}$, this compound can give off $\mathrm{H}_{2}$ at temperatures below or at $80{ }^{\circ} \mathrm{C}$, with the formation of a single dehydrogenation product that is also a liquid at room temperature. The authors have also demonstrated the conversion of the dehydrogenated 65 product back to the charged fuel with a 92\% yield under relatively mild conditions. Although the material capacity (4.7 wt\%) falls short of the 2017 target for automobile applications (5.5 wt\% system), ${ }^{23}$ this research demonstrates a viable $\mathrm{H}_{2}$ storage option for portable and carrier applications.

70 As the complex decomposes to a liquid product, this approach enables a much simpler system design with respect to fuel feed and recovery. In addition, the low dehydrogenation temperature indicates that waste heat from a proton exchange membrane fuel cell can be used, which allows a highly efficient use of energy. 75 As noted by the authors, to make the process cost-effective, an 
economical regeneration process needs to be developed.

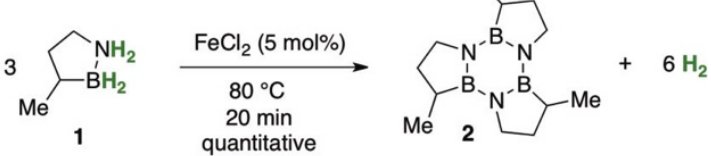

Scheme 3 A single-component liquid-phase hydrogen storage material. Reprinted with permission from Ref. 132. Copyright (2011) American Chemical Society.

\section{Applications in hydrogenation}

${ }_{5}$ Due to its high hydrogen content and reducing capability, AB has also been studied as a hydrogenating agent in organic syntheses, such as converting aldehydes to alcohols ${ }^{133-135}$ and reducing cyclohexyl imines and iminium salts. ${ }^{136}$ In those studies, AB was thought to transfer hydridic $\mathrm{H}$ on boron to unsaturated functional 10 groups. Recent work, however, reveals a different mechanism. Berke and co-workers found that $\mathrm{AB}$ reduces imine through a concerted double hydrogen transfer process, where the protic $\mathrm{H}(\mathrm{N})$ and hydridic $\mathrm{H}(\mathrm{B})$ are transferred to the nitrogen and carbon ends of the imine group, respectively. ${ }^{137}$ This double15 hydrogen transfer process was also observed by Manner et al. in the case of $\mathrm{N}=\mathrm{B}$ double bond reduction, ${ }^{138}$ and by Chen during the hydrogenation of aromatic aldehydes by $\mathrm{AB} .{ }^{139}$

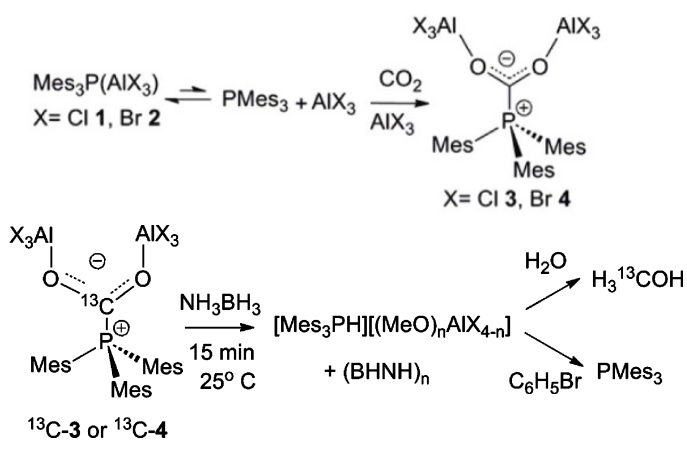

Scheme 4 Synthesis of $\mathrm{PMes}_{3} / \mathrm{AlX}_{3}, \mathrm{Mes}_{3} \mathrm{P}\left(\mathrm{CO}_{2}\right)(\mathrm{AlX})_{2}(\mathrm{X}=\mathrm{Cl}$, $\mathrm{Br}$ ) (top) and the formation of $\mathrm{CH}_{3} \mathrm{OH}$ upon adding $\mathrm{AB}$ followed by $\mathrm{H}_{2} \mathrm{O}$ (bottom). Reprinted with permission from Ref. 142. Copyright (2010) American Chemical Society.

This double-electron transfer process also renders $A B$ 20 applicable in renewable energy research from a different perspective. It is well known that $\mathrm{CO}_{2}$ is the main contributing factor to global warming and climate change. Reduction of $\mathrm{CO}_{2}$ to a useful fuel such as methanol has surfaced as a chemical challenge of great interest. Due to its limited reactivity, $\mathrm{CO}_{2}$ 25 reduction is currently achieved by using electrocatalysts or heterogeneous photocatalysts that involve transition-metal containing complexes and materials. ${ }^{140,141}$ Recently, Stephan et al. described a rapid, room temperature conversion of frustrated Lewis pair (FLP)-activated $\mathrm{CO}_{2}$ to $\mathrm{CH}_{3} \mathrm{OH}$ using $\mathrm{AB}$ as the 30 hydrogen source, without the assistance of a transition metal (Scheme 4). ${ }^{142}$ First, $\mathrm{PMes}_{3}\left(\mathrm{Mes}=2,4,6-\mathrm{C}_{6} \mathrm{H}_{2} \mathrm{Me}_{3}\right)$ and $\mathrm{AlX}_{3}(\mathrm{X}$
$=\mathrm{Cl}, \mathrm{Br}$ ) react to form weak Lewis adducts, which then can react irreversibly with $\mathrm{CO}_{2}$. After the solution reacts with $\mathrm{AB}, \mathrm{H}_{2} \mathrm{O}$ is introduced to produce $\mathrm{CH}_{3} \mathrm{OH}$, which can be extracted with a 35 decent yield of $37-51 \%$. Theoretical investigations by Zimmerman et al. suggested that $\mathrm{AB}$ reduces $\mathrm{CO}_{2}$ through the two-hydrogen transfer process. ${ }^{32,143}$ This pioneering research is expected to provide valuable insights for developing strategies for $\mathrm{CO}_{2}$ reduction using $\mathrm{AB}$ as an efficient reducing agent, although 40 regeneration of $\mathrm{AB}$ from the end products will be challenging, since $\mathrm{B}-\mathrm{O}$ bonds tend to form upon adding $\mathrm{H}_{2} \mathrm{O}$. The ultimate economic impact is likely to be dependent on the energy output from consuming $\mathrm{CH}_{3} \mathrm{OH}$ versus the energy input from converting $\mathrm{B}-\mathrm{O}$ to $\mathrm{B}-\mathrm{H}$ in a catalytic regeneration reaction.

45 In a related report Ashley and co-workers demonstrated that an amine borane complex could be used to activate both hydrogen and $\mathrm{CO}_{2}$ to make $\mathrm{CH}_{3} \mathrm{OH}$ in a stoichiometric reaction. ${ }^{144}$

\section{Catalysis}

Prior to Welch and Stephan's observation that $\mathrm{H}_{2}$ could be added 50 reversibly across a frustrated Lewis pair of phosphine and borane, ${ }^{145}$ the common dogma was that metals were required to activate hydrogen. Sumerin and co-workers, however, demonstrated reversible hydrogen addition to a structurally linked amine borane complex (Scheme 5). ${ }^{146}$

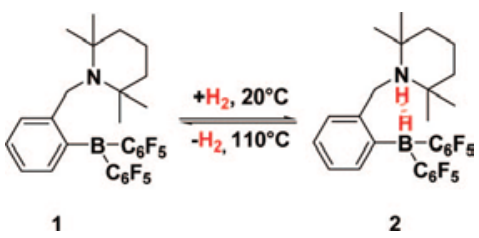

Scheme 5 Reversible $\mathrm{H}_{2}$ activation by N-TMPN$\mathrm{CH}_{2} \mathrm{C}_{6} \mathrm{H}_{4} \mathrm{~B}\left(\mathrm{C}_{6} \mathrm{~F}_{5}\right)_{2}$ (where TMPNH is 2,2,6,6tetramethylpiperidinyl). Reprinted with permission from Ref. 146. Copyright (2010) American Chemical Society.

55 This was the first example of reversible 'hydrogen storage' in an amine borane complex. While the quantity of hydrogen is too low to be of practical significance for hydrogen storage applications, it is an important result because it shows that amine borane complexes can be used to activate hydrogen at moderate 60 temperature and pressure to be used in catalytic reduction reactions. Since these pioneering studies, there have been several examples demonstrating the catalytic reduction of unsaturated polar molecules by a wide range of amine-borane frustrated Lewis pairs. ${ }^{147}$ This is an exciting new area of research using 65 amine boranes for applications beyond hydrogen storage, and the field is rapidly growing with new examples of hydrogen activation for catalysis being reported.

\section{Synthesis of new inorganic analogues}

Serendipity has again made an amazingly good appearance with 70 the reports of new BNH compounds during these extensive studies, which further enriches the chemistry of boron. Studying the activating effects of Verkade' s base (VB), 2,8,9-triisobutyl2,5,8,9-tetraaza-1-phosphabicyclo [3.3.3] undecane, on the rate and extent of $\mathrm{H}_{2}$ release from $\mathrm{AB}$, Sneddon's group discovered 75 the formation of $\left[\mathrm{C}_{18} \mathrm{H}_{39} \mathrm{~N}_{4} \mathrm{PH}\right]\left[\mathrm{H}_{3} \mathrm{BNH}_{2} \mathrm{BH}_{2} \mathrm{NH}_{2} \mathrm{BH}_{3}\right]$, 
$\left[\mathrm{C}_{18} \mathrm{H}_{39} \mathrm{~N}_{4} \mathrm{PH}\right]\left[\mathrm{HB}\left(\mathrm{NH}_{2} \mathrm{BH}_{3}\right)_{3}\right]$,

and

$\left[\mathrm{C}_{18} \mathrm{H}_{39} \mathrm{~N}_{4} \mathrm{PH}\right]\left[\mathrm{H}_{3} \mathrm{BNH}_{2} \mathrm{BH}_{2} \mathrm{NH}_{2} \mathrm{BH}_{2} \mathrm{NH}_{2} \mathrm{BH}_{3}\right]$ (Scheme 6), which are isoelectronic and isostructural analogues of the hydrocarbons n-pentane, 3-ethylpentane, and n-heptane, respectively. ${ }^{34}$ ${ }_{5}$ Considering the synthesis conditions (room-temperature for the five-membered and $50{ }^{\circ} \mathrm{C}$ for the seven-membered compounds), these anionic aminoborane oligomers are likely to be early intermediates in base-promoted $\mathrm{AB} \mathrm{H}_{2}$ release reactions. Sequential $\mathrm{H}_{2}$ elimination reactions lead to chain growth, which 10 is likely facilitated by $\mathrm{N}-\mathrm{H}^{\delta+} \cdots \mathrm{H}^{\delta-}-\mathrm{B}$ dihydrogen-bonding interactions in these anionic aminoborane chains.

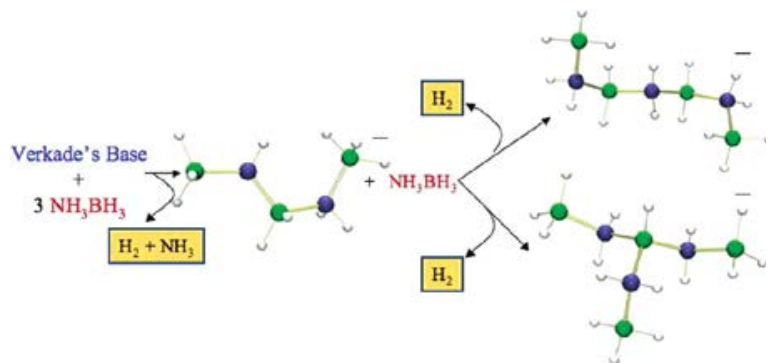

Scheme 6 Synthesis of $\left[\mathrm{C}_{18} \mathrm{H}_{39} \mathrm{~N}_{4} \mathrm{PH}\right]\left[\mathrm{H}_{3} \mathrm{BNH}_{2} \mathrm{BH}_{2} \mathrm{NH}_{2} \mathrm{BH}_{3}\right]$, $\left[\mathrm{C}_{18} \mathrm{H}_{39} \mathrm{~N}_{4} \mathrm{PH}\right]\left[\mathrm{HB}\left(\mathrm{NH}_{2} \mathrm{BH}_{3}\right)_{3}\right]$,

and $\left[\mathrm{C}_{18} \mathrm{H}_{39} \mathrm{~N}_{4} \mathrm{PH}\right]\left[\mathrm{H}_{3} \mathrm{BNH}_{2} \mathrm{BH}_{2} \mathrm{NH}_{2} \mathrm{BH}_{2} \mathrm{NH}_{2} \mathrm{BH}_{3}\right]$ via reactions between Verkade's base and $\mathrm{AB}$. B: green; N: navy; H: light grey. Reprinted with permission from Ref. 34. Copyright (2011) American Chemical Society.

Aminodiborane $\left(\mathrm{NH}_{2} \mathrm{~B}_{2} \mathrm{H}_{5}\right)$ was first discovered 70 years ago through a tedious procedure using $\mathrm{B}_{2} \mathrm{H}_{6} \cdot{ }^{148}$ Little subsequent 15 study has occurred because of its scarce availability. Recently, Chen et al. found that when $\mathrm{AB}$ and $\mathrm{THF} \cdot \mathrm{BH}_{3}$ were mixed together at room temperature, $\mathrm{NH}_{2} \mathrm{~B}_{2} \mathrm{H}_{5}$ was formed via the formation of a dihydrogen bond and subsequent molecular hydrogen elimination (Scheme 7). ${ }^{36}$ A concentrated $20 \mathrm{NH}_{2} \mathrm{~B}_{2} \mathrm{H}_{5}$. THF solution (1:1 ratio, based upon the integration of the hydrogen signals in the ${ }^{1} \mathrm{H}$ NMR spectrum) can be obtained with a yield of $70 \%$. When $\mathrm{NH}_{3}$ was bubbled into a solution of $\mathrm{NH}_{2} \mathrm{~B}_{2} \mathrm{H}_{5}$, an inorganic butane analogue, $\mathrm{NH}_{3} \mathrm{BH}_{2} \mathrm{NH}_{2} \mathrm{BH}_{3}$, was formed, a reaction which likely proceeded via the breaking of the 25 bridge hydrogen bond in $\mathrm{NH}_{2} \mathrm{~B}_{2} \mathrm{H}_{5}$ (Scheme 7).

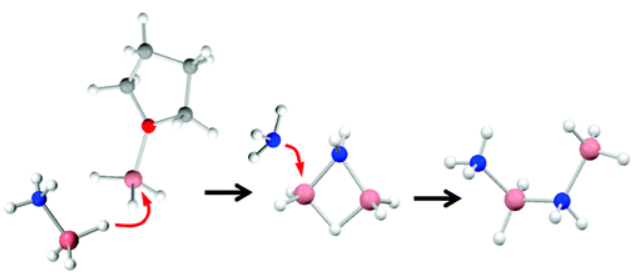

Scheme 7 Formation of $\mathrm{NH}_{2} \mathrm{~B}_{2} \mathrm{H}_{5}$ and $\mathrm{NH}_{3} \mathrm{BH}_{2} \mathrm{NH}_{2} \mathrm{BH}_{3}$. B: purple, $\mathrm{N}$ : blue, $\mathrm{H}$ : light grey. Reprinted with permission from Ref. 36. Copyright (2010) American Chemical Society.

Another breakthrough occurred in the syntheses of the longsought unsubstituted aminodiboranate $\mathrm{Na}\left(\mathrm{H}_{3} \mathrm{BNH}_{2} \mathrm{BH}_{3}\right)$ and its $\mathrm{N}$-alkyl analogs. ${ }^{35}\left[\mathrm{NH}_{4}\right]\left[\mathrm{H}_{3} \mathrm{BNH}_{2} \mathrm{BH}_{3}\right]$ was first proposed by ${ }_{30}$ Schlesinger and Berg to formulate $\mathrm{DADB},{ }^{96}$ although later spectroscopic studies established that DADB is actually the borohydride salt $\left[\left(\mathrm{NH}_{3}\right)_{2} \mathrm{BH}_{2}\right]\left[\mathrm{BH}_{4}\right]$. After being neglected for about 80 years, this anion was proved to exist by Girolami et al., who found that when $\mathrm{AB}$ with excess $\mathrm{Na}$ in THF was subject to 35 reflux, $\mathrm{Na}\left(\mathrm{H}_{3} \mathrm{BNH}_{2} \mathrm{BH}_{3}\right)$ is formed. This new compound displays a downfield ${ }^{11} \mathrm{~B}$ NMR chemical shift compared with $\mathrm{AB}$ and $\mathrm{NaNH}_{2} \mathrm{BH}_{3}$ (Fig. 13). ${ }^{35}$ Similar reactions with other amineboranes afford $\mathrm{Na}\left(\mathrm{H}_{3} \mathrm{BNRR} \mathrm{BH}_{3}\right) . \mathrm{Na}\left(\mathrm{H}_{3} \mathrm{BNH}_{2} \mathrm{BH}_{3}\right)$ can also be generated by reaction of 2 equivalent of $\mathrm{AB}$ with $\mathrm{NaNH}_{2}$ in 40 refluxing $\mathrm{THF}$, which results in a better yield (50\%).

$4 \mathrm{HNRR}^{\prime} \cdot \mathrm{BH}_{3}+2 \mathrm{Na} \rightarrow 2 \mathrm{Na}\left(\mathrm{H}_{3} \mathrm{BNRR}^{\prime} \mathrm{BH}_{3}\right)+\mathrm{H}_{2}+2 \mathrm{HNRR}^{\prime}(6)$

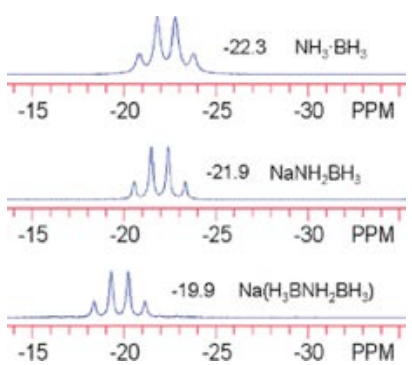

Fig. $13{ }^{11} \mathrm{~B}$ NMR spectra of $\mathrm{AB}, \mathrm{Na}\left(\mathrm{NH}_{2} \mathrm{BH}_{3}\right)$, and $\mathrm{Na}\left(\mathrm{H}_{3} \mathrm{BNH}_{2} \mathrm{BH}_{3}\right)$. Reprinted with permission from Ref. 35 . Copyright (2010) American Chemical Society.

\section{Conclusion}

${ }_{45}$ Whether BNH compounds hold the key to hydrogen storage remains uncertain, but the current renewed interest and strong efforts have so far resulted in a much improved understanding of boron chemistry. There has been enhanced recognition of the $\mathrm{H}-$ $\mathrm{H}$ interactions, including both $\mathrm{N}-\mathrm{H}^{\delta+} \ldots{ }^{\delta-} \mathrm{H}-\mathrm{B}$ (dihydrogen bond) 50 and the homopolar interactions, B- $\mathrm{H}^{\delta-} \ldots{ }^{\delta-} \mathrm{H}-\mathrm{B}$ and $\mathrm{N}-\mathrm{H}^{\delta+} \ldots{ }^{\delta+} \mathrm{H}-$ $\mathrm{N}$, in relation to crystal structure and $\mathrm{H}_{2}$ evolution. The development of safe and efficient syntheses of existing compounds will enable further studies of their applications. The discovery of new compounds certainly enriches the field of boron 55 chemistry by opening up room for new syntheses and new applications. The catalysis and hydrogenation work using ammine borane complexes is exciting; few chemists would have suggested just over 6 years ago that hydrogen could be activated at low temperature and pressure without using transition metals.

60 The employment of modern advanced techniques, such as high field solid state NMR spectrometers and high level density functional theory (DFT) calculation tools, together with worldwide collaborations, offers a very strong edge over the studies in the 1950s. It has to be acknowledged, however, that the 65 pioneering work carried out by A. Stock, H. I. Schlesinger, D. M. Ritter, A. B. Burg, P. W. Parry, M. F. Hawthorne, H. C. Brown, S. G. Shore, etc. has laid a solid foundation for the work of today. Their earlier experimental findings and speculations are often referred to and provide guidance for today's research. Likewise, 70 today's outcomes will also shed light on future research in this field. 
Table 2 Reviewed compounds for hydrogen storage.

\begin{tabular}{|c|c|c|c|c|c|c|}
\hline \multirow{2}{*}{ Compounds } & \multicolumn{2}{|c|}{ Density } & \multirow{2}{*}{$\begin{array}{c}\text { Onset release } \\
\text { temperature } \\
\left({ }^{\circ} \mathrm{C}\right)\end{array}$} & \multirow{2}{*}{$\begin{array}{l}\text { Enthalpy } \\
(\mathrm{kJ} / \mathrm{mol})\end{array}$} & \multirow{2}{*}{ Impurities } & \multirow{2}{*}{ References } \\
\hline & wt $\% \mathrm{H}_{2}$ & $\mathrm{~g} \mathrm{H}_{2} / \mathrm{L}$ & & & & \\
\hline $\mathrm{NH}_{3} \mathrm{BH}_{3}$ & 19.4 & 144 & 108 & -23 & $\mathrm{~B}_{2} \mathrm{H}_{6}, \mathrm{~B}_{3} \mathrm{~N}_{3} \mathrm{H}_{6}, \mathrm{NH}_{3}$ & 19,20 \\
\hline $\mathrm{LiNH}_{2} \mathrm{BH}_{3}$ & 10.9 & 52 & 92 & $-3--5$ & $\mathrm{NH}_{3}$ & 91 \\
\hline $\mathrm{NaNH}_{2} \mathrm{BH}_{3}$ & 7.6 & 43 & 89 & $-3--5$ & $\mathrm{NH}_{3}$ & 149 \\
\hline$\left[\left(\mathrm{NH}_{3}\right)_{2} \mathrm{BH}_{2}\right]\left[\mathrm{BH}_{4}\right]$ & 19.4 & 151 & 85 & -34 & $\mathrm{~B}_{2} \mathrm{H}_{6}, \mathrm{~B}_{3} \mathrm{~N}_{3} \mathrm{H}_{6}, \mathrm{NH}_{3}$ & $29,98,99$ \\
\hline $\mathrm{NH}_{4} \mathrm{~B}_{3} \mathrm{H}_{8}$ & 20.5 & 160 & 120 & Not reported & $\mathrm{B}_{3} \mathrm{~N}_{3} \mathrm{H}_{6}, \mathrm{~B}_{2} \mathrm{H}_{6}, \mathrm{~B}_{5} \mathrm{H}_{9}$ & 116 \\
\hline $\mathrm{BH}_{3} \mathrm{NH}_{2} \mathrm{CH}_{2} \mathrm{CH}_{2} \mathrm{NH}_{2} \mathrm{BH}_{3}$ & 10 & 82 & 123 & $\begin{array}{l}\left.-10 \text { ( } 1^{\text {st }} \text { step }\right) \\
-4\left(2^{\text {nd }} \text { step }\right)\end{array}$ & Not observed & 128 \\
\hline$\left(\mathrm{NH}_{3}\right)_{2} \mathrm{BH}_{2} \mathrm{~B}_{3} \mathrm{H}_{8}$ & 18.2 & Not reported & 100 & Not reported & $\mathrm{B}_{3} \mathrm{~N}_{3} \mathrm{H}_{6}, \mathrm{~B}_{2} \mathrm{H}_{6}, \mathrm{~B}_{5} \mathrm{H}_{9}$ & 125 \\
\hline $\mathrm{C}_{4} \mathrm{H}_{12} \mathrm{BN}$ & 4.7 & 42 & 150 & Not reported & Not observed & 132 \\
\hline
\end{tabular}

Note: U.S. DOE has recently compiled a database on hydrogen storage materials. ${ }^{150}$ Variation in desorption temperatures and enthalpy has been observed. Please refer to the specific experimental conditions.

\section{Acknowledgements}

Z. H. is the recipient of a Discovery Early Career Research Award conferred by the Australian Research Council (Project No. DE120101496). T. A. acknowledges support from the U.S. 5 Department of Energy's Basic Energy Sciences, Division of Chemical Sciences, Biosciences and Geosciences. Pacific Northwest National Laboratory is operated by Battelle.

\section{References}

101 H. C. Brown, Boranes in Organic Chemistry, Cornell University Press, Ithaca, NY, 1972, pp. 41-49.

2 A. Dequasie, The Green Flame: Surviving Government Secrecy, American Chemical Society, Washington DC, 1991.

3 H. C. Brown, H. I. Schlesinger, I. Sheft and D. M. Ritter, J. Am.

15 Chem. Soc., 1953, 75, 192.

4 H. I. Schlesinger, H. C. Brown, J. R. Gilbreath and J. J. Katz, J. Am. Chem. Soc., 1953, 75, 195.

5 H. I. Schlesinger, H. C. Brown and A. E. Finholt, J. Am. Chem. Soc., 1953, 75, 205

206 H. I. Schlesinger and H. C. Brown, J. Am. Chem. Soc., 1953, 75, 219.

7 H. I. Schlesinger, H. C. Brown and E. K. Hyde, J. Am. Chem. Soc., 1953, 75, 209.

8 H. I. Schlesinger, H. C. Brown, A. E. Finholt, J. R. Gilbreath, H. R. Hoekstra and E. K. Hyde, J. Am. Chem. Soc., 1953, 75, 215.

259 J. M. Abboud, B. Németh, J. -C. Guillemin, P. Burk, A. Adamson and E. R. Nerut, Chem. Eur. J., 2012, 18, 3981.

10 Z. T. Xiong, G. T. Wu, Y. S. Chua, J. J. Hu, T. He, W. L. Xu and P. Chen, Energy Environ. Sci., 2008, 1, 360.

11 D. J. Heldebrant, A. Karkamkar, J. C. Linehan and T. Autrey, Energy Environ. Sci., 2008, 1, 156.

12 T. He, H. Wu, G. Wu, J. Wang, W. Zhou, Z. Xiong, J. Chen, T. Zhang and P. Chen, Energy Environ. Sci., 2012, 5, 5686.

13 H. Wu, W. Zhou, F. E. Pinkerton, T. J. Udovic, T. Yildirim and J. J. Rush, Energy Environ. Sci., 2012, 5, 7531.

3514 D. W. Himmelberger, C. W. Yoon, M. E. Bluhm, P. J. Carroll and L. G. Sneddon, J. Am. Chem. Soc., 2009, 131, 14101.

15 M. E. Bluhm, M. G. Bradley, R. Butterick III, U. Kusari and L. G. Sneddon, J. Am. Chem. Soc., 2006, 128, 7748.

16 J. Hannauer, O. Akdim, U. B. Demirci, C. Geantet, J. -M. Herrmann, P. Miele and Q. Xu, Energy Environ. Sci., 2011, 4, 3355.

17 U. B. Demirci and P. Miele, Energy Environ. Sci., 2009, $2,627$.

18 P. Wang and X. Kang, Dalton Trans., 2008, 40, 5400.

19 M. G. Hu, R. A. Geanangel and W. W. Wendlant, Thermochim. Acta, 1978, 23, 249

4520 G. Wolf, J. Baumann, F. Baitalow and F. P. Hoffmann, Thermochim. Acta, 2000, 343, 19.
21 K. R. Graham, T. Kemmitt and M. E. Bowden, Energy Environ. Sci., 2009, 2, 706.

22 K. C. Ott. Final Report for the DOE Chemical Hydrogen Storage

50 Center of Excellence.

http://www1.eere.energy.gov/hydrogenandfuelcells/pdfs/chemical_hy drogen_storage_coe_final_report.pdf

23 Targets for Onboard Hydrogen Storage Systems for Light-Duty Vehicles. US Department of Energy Office of Energy Efficiency and Renewable Energy and The FreedomCAR and Fuel Partnership. September 2009.

http://www1.eere.energy.gov/hydrogenandfuelcells/storage/pdfs/ targets_onboard_hydro_storage.pdf.

24 Peak power demands in a PEM fuel cell require approximately $0.02 \mathrm{~g}$ $\mathrm{H}_{2} / \mathrm{sec} / \mathrm{kW}$.

25 S. D. Rassat, C. L. Aardahl, T. Autrey and R. S. Smith, Energy Fuels, 2010, 24, 2596.

26 A. C. Stowe, W. J. Shaw, J. C. Linehan, B. Schmid and T. Autrey, Phys. Chem. Chem. Phys., 2007, 9, 1831.

6527 M. Bowden, T. Autrey, I. Brown and M. Ryan, Curr. Appl. Phys., 2008, 8, 498.

28 W. J. Shaw, J. C. Linehan, N. K. Szymczak, D. J. Heldebrant, C. Yonker, D. M. Camaioni, R. T. Baker and T. Autrey, Angew. Chem., Int. Ed., 2008, 47, 7493.

7029 M. Bowden and T. Autrey, Current Opinion in Solid State \& Materials Science, 2011, 15, 73.

30 G. R. Whittell and I. Manners, Angew. Chem., Int. Ed., 2011, 50, 10288.

31 T. Autrey, M. Bowden and A. Karkamkar, Faraday Discuss., 2011, 151, 157.

32 L. Roy, P. M. Zimmerman and A. Paul, Chem. Eur. J., 2011, 17, 435.

33 L. Song, L. Ci, H. Lu, P. B. Sorokin, C. Jin, J. Ni, A. G. Kvashnin, D. G. Kvashnin, J. Lou, B. I. Yakobson and P. M. Ajayan, Nano Lett., 2010, 10, 3209.

8034 W. C. Ewing, A. Marchione, D. W. Himmelberger, P. J. Carroll and L. G. Sneddon, J. Am. Chem. Soc., 2011, 133, 17093.

35 S. R. Daly, B. J. Bellott, D. Y. Kim and G. S. Girolami, J. Am. Chem. Soc., 2010, 132, 7254.

36 X. Chen, J. -C. Zhao and S. G. Shore, J. Am. Chem. Soc., 2010, 132, 8510658.

37 C. W. Hamilton, R. T. Baker, A. Staubitz and I. Manners, Chem. Soc. Rev., 2009, 38, 279.

38 N. C. Smythe and J. C. Gordon, Eur. J. Inorg. Chem., 2010, 509.

39 A. Staubitz, A. P. M. Robertson and I. Manners, Chem. Rev., 2010,

$90 \quad$ 110, 4079.

40 P. Wang, Dalton Trans., 2012, 41, 4296.

41 F. H. Stephens, V. Pons and R. T. Baker, Dalton Trans., 2007, 25, 2613.

42 Y. Tan, Y. Guo, S. Li, W. Sun, Y. Zhu, Q. Li and X. Yu, J. Mater. $95 \quad$ Chem., 2011, 21, 14509. 
43 T. B. Richardson, S. Gala and R. H. Crabtree, J. Am. Chem. Soc., 1995, 117, 12875.

44 H. Wu, W. Zhou, F. E. Pinkerton, T. J. Udovic, T. Yildirimad and J. J. Rush, Energy Environ. Sci., 2012, 5, 7531.

545 W. J. Shaw, M. Bowden, A. Karkamkar, C. J. Howard, D. J. Heldebrant, N. J. Hess, J. C. Linehan and T. Autrey, Energy Environ. Sci., 2010, 3, 796.

46 H. Wu, W. Zhou, F. E. Pinkerton, M. S. Meyer, G. Srinivas, T. Yildirim, T. J. Udovic and J. J. Rush, J. Mater. Chem., 2010, 20,

$10 \quad 6550$

47 Y. Li, F. Fang, Y. Song, Y. Li, Q. Zhang, L. Ouyang, M. Zhu and D. Sun, Int. J. Hydrogen Energy, 2012, 37, 4274.

48 Y. Yamada, K. Yano and S. Fukuzumi, Energy Environ. Sci., 2012, 5, 5356.

1549 P. -Z. Li, K. Aranishi and Q. Xu, Chem. Commun., 2012, 48, 3173.

50 D. Sun, V. Mazumder, Ö. Metin and S. Sun, ACS Nano, 2011, 5, 6458.

51 D. Neiner, A. Luedtke, A. Karkamkar, W. Shaw, J. Wang, N. D. Browning, T. Autrey and S. M. Kauzlarich, J. Phys. Chem. C, 2010,

$20 \quad \mathbf{1 1 4}, 13935$.

52 J. Luo, X. Kang, Z. Fang and P. Wang, Dalton Trans., 2011, 40, 6469.

53 Z. Tang, H. Chen, X. Chen, L. Wu and X. Yu, J. Am. Chem. Soc., 2012, 134, 5464.

2554 Y. Zhao, J. Zhang, D. L. Akins and J. W. Lee, Ind. Eng. Chem. Res., 2011, 50, 10024.

55 R. T. Baker, J. C. Gordon, C. W. Hamilton, N. J. Henson, P. -H. Lin, S. Maguire, M. Murugesu, B. L. Scott and N. C. Smythe, J. Am. Chem. Soc., 2012, 134, 5598.

3056 B. L. Conley, D. Guess and T. J. Williams, J. Am. Chem. Soc., 2011, 133, 14212.

57 S. -K. Kim, W. -S. Han, T. -J. Kim, T. -Y. Kim, S. W. Nam, M. Mitoraj, Ł. Piekoś, A. Michalak, S. -J. Hwang and S. O. Kang, J. Am. Chem. Soc., 2010, 132, 9954.

3558 W. R. H. Wright, E. R. Berkeley, L. R. Alden, R. T. Baker and L. G. Sneddon, Chem. Commun., 2011, 47, 3177.

59 D. W. Himmelberger, L. R. Alden, M. E. Bluhm, P. J. Carroll and L. G. Sneddon, Inorg. Chem., 2009, 48, 9883.

60 J. F. Kostka, R. Schellenberg, F. Baitalow, T. Smolinka and F.

$40 \quad$ Mertens, Eur. J. Inorg. Chem., 2012, 49.

61 A. McClaine, Chemical Hydride Slurry for Hydrogen Production and Storage, Final Report. DOI: 10.2172/940573

62 U. S. DOE, 2012 Annual Merit Review and Peer Evaluation Report, http://www.hydrogen.energy.gov/pdfs/review12/st000_stetson_2012

45 _o.pdf

63 B. L. Davis, D. A. Dixon, E. B. Garner, J. C. Gordon, M. H. Matus and B. Scott, Angew. Chem., Int. Ed., 2009, 48, 6812.

64 A. Staubitz, M. E. Sloan, A. P. M. Robertson, A. Friedrich, S. Schneider, P. J. Gates, J. Schmedt auf der Günne and I. Manners, J. Am. Chem. Soc., 2010, 132, 13332.

65 M. Käß, A. Friedrich, M. Drees and S. Schneider, Angew. Chem., Int. Ed., 2009, 48, 905.

66 N. Blaquiere, S. Diallo-Garcia, S. I. Gorelsky, D. A. Black and K. Fagnou, J. Am. Chem. Soc., 2008, 130, 14034.

${ }_{55} 67$ M. C. Denney, V. Pons, T. J. Hebden, D. M. Heinekey and K. I. Goldberg, J. Am. Chem. Soc., 2006, 128, 12048.

68 J. R. Vance, A. P. M. Robertson, K. Lee and I. Manners, Chem. Eur. J., 2011, 17, 4099.

69 D. J. Heldebrant, A. Karkamkar, N. J. Hess, M. Bowden, S. Rassat,

$60 \quad$ F. Zheng, K. Rappe and T. Autrey, Chem. Mater., 2008, 20, 5332.

70 S. B. Kalidindi, J. Joseph and B. R. Jagirdar, Energy Environ. Sci., 2009, 2, 1274.

71 C. -H. Sun, X. -D. Yao, A. -J. Du, L. Li, S. Smith and G. -Q. Lu, Phys. Chem. Chem. Phys., 2008, 10, 6104.

6572 T. He, Z. Xiong, G. Wu, H. Chu, C. Wu, T. Zhang and P. Chen, Chem. Mater., 2009, 21, 2315.

73 S. -K. Kim, T. -J. Kim, T. -Y. Kim, G. Lee, J. T. Park, S. W. Nam and S. O. Kang, Chem. Commun., 2012, 48, 2021.

74 S. Karahan, M. Zahmakıran and S. Özkar, Chem. Commun., 2012,

$70 \quad \mathbf{4 8}, 1180$
75 Z. Tang, S. Li, Z. Yang and X. Yu, J. Mater. Chem., 2011, 21, 14616.

76 Z. Xiong, C. K. Yong, G. Wu, P. Chen, W. Shaw, A. Karkamkar, T. Autrey, M. O. Jones, S. R. Johnson, P. P. Edwards and W. I. F. David, Nat. Mater., 2008, 7, 138.

77 S. A. Shevlin, B. Kerkeni and Z. X. Guo, Phys. Chem. Chem. Phys., 2011, 13, 7649.

78 K. J. Fijalkowski, R. V. Genova, Y. Filinchuk, A. Budzianowski, M. Derzsi, T. Jaroń, P. J. Leszczyński and W. Grochala, Dalton Trans., 2011, 40, 4407.

79 X. Kang, J. Luo, Q. Zhang and P. Wang, Dalton Trans., 2011, 40, 3799.

80 H. V. K. Diyabalanage, R. P. Shrestha, T. A. Semelsberger, B. L. Scott, M. E. Bowden, B. L. Davis and A. K. Burrell, Angew. Chem.,

85 Int. Ed., 2007, 46, 8995.

81 A. T. Luedtke and T. Autrey, Inorg. Chem., 2010, 49, 3905.

82 D. Y. Kim, H. M. Lee, J. Seo, S. K. Shin and K. S. Kim, Phys. Chem. Chem. Phys., 2010, 12, 5446.

83 T. B. Lee and M. L. McKee, Inorg. Chem., 2009, 48, 7564.

9084 D. J. Wolstenholme, J. T. Titah, F.N. Che, K. T. Traboulsee, J. Flogeras and G. S. McGrady, J. Am. Chem. Soc., 2011, 133, 16598.

85 P. J. Fazen, E. E. Remsen, J. S. Beck, P. J. Carroll, A. R. McGhie and L. G. Sneddon, Chem. Mater., 1995, 7, 1942.

86 S. Hausdorf, F. Baitalow, G. Wolf and F. O. R. L. Mertens, Int. J. Hydrogen Energy, 2008, 33, 608.

87 A. D. Sutton, B. L. Davis, K. X. Bhattacharyya, B. D. Ellis, J. C. Gordon and P. P. Power, Chem. Commun., 2010, 46, 148.

88 D. L. DuBois, D. M. Blake, A. Miedaner, C. J. Curtis, M. R. DuBois, J. A. Franz and J. C. Linehan, Organometallics, 2006, 25, 4414.

10089 M. T. Mock, R. G. Potter, D. M. Camaioni, J. Li, W. G. Dougherty, W. S. Kassel, B. Twamley and D. L. DuBois, J. Am. Chem. Soc., 2009, 131, 14454.

90 M.T. Mock, R. G. Potter, M.J. O'Hagan, D. M. Camaioni, W. G. Dougherty, W. S. Kassel and D. L. DuBois, Inorg. Chem., 2011, 50,

10511914.

91 C. Aardahl, T. Autrey, D. Camaioni, D. Dubois, J. Linehan, A. Karkamkar, S. Rassat, R. Zheng, W. Shaw, J. Li, D. Heldebrant, R. Potter, M. Mock, A. Luedtke and T. Smurthwaite, "Chemical Hydrogen Storage Research at PNNL”, U.S. DOE Annual Report, 2009.

92 R. G. Potter and D. M. Camaioni, M. Vasiliu and D. A. Dixon, Inorg. Chem., 2010, 49, 10512.

93 A. D. Sutton, A. K. Burrell, D. A. Dixon, E. B. Garner III, J. C. Gordon, T. Nakagawa, K. C. Ott, J. P. Robinson and M. Vasiliu, 115 Science, 2011, 331, 1426.

94 E. Wiberg, Z. Anorg. Allg. Chem., 1928, 173, 199.

95 A. Stock and E. Pohland, Ber. Dtsch. Chem. Ges., 1926, 59, 2215.

96 H. I. Schlesinger and A. B. Burg, J. Am. Chem. Soc., 1938, 60, 290.

97 S. G. Shore and R. W. Parry, J. Am. Chem. Soc., 1955, 77, 6084.

12098 M. Bowden, D. J. Heldebrant, A. Karkamkar, T. Proffen, G. K. Schenter and T. Autrey, Chem. Commun., 2010, 46, 8564.

99 Z. Fang, J. Luo, X. Kang, H. Xia, S. Wang, W. Wen, X. Zhou and P. Wang, Phys. Chem. Chem. Phys., 2011, 13, 7508.

100 H. K. Lingam, X. Chen, J. -C. Zhao and S. G. Shore, Chem. Eur. J., $125 \quad 2012, \mathbf{1 8}, 3490$.

101 C. W. Yoon and L. G. Sneddon, J. Am. Chem. Soc., 2006, 128, 13992.

102 C. W. Yoon, P. J. Carroll and L. G. Sneddon, J. Am. Chem. Soc., 2009, 131, 855.

130103 D. Gaines, R. Schaeffer and F. Tabbe, Inorg. Chem., 1963, 2, 526.

104 H. C. Miller, N. E. Miller and E. L. Muetterties, Inorg. Chem., 1964, 3, 1456.

105 L. V. Titov, E. R. Eremin and V. Y. Rosolovskii, Russ. J. Inorg. Chem. (Engl. Transl.), 1982, 27, 500.

135106 C. Serrar and A. Ouassas, Synth. React. Inorg. Met. -Org. Chem., 1996, 26, 669

107 L. V. Titov, Russ. J. Inorg. Chem. (Engl. Transl.), 2003, 48, 1471.

108 I. S. Antonov, M. A. Pchelkina, V. S. Nikitin, G. A. Egorenko, Z. F. Vinogradova and A. T. Kurekova, Russ. J. Inorg. Chem. (Engl. Transl.), 1973, 18, 321. 
109 W. V. Hough, L. J. Edwards and A. D. McElroy, J. Am. Chem. Soc., 1956, 78, 689.

110 D. M. Goedde, G. K. Windler and G. S. Girolami, Inorg. Chem., 2007, 46, 2814.

5111 Z. Huang, G. King, X. Chen, J. Hoy, T. Yisgedu, H. K. Lingam, S. G. Shore, P. M. Woodward and J. -C. Zhao, Inorg. Chem., 2010, 49, 8185.

112 M. Chong, A. Karkamkar, T. Autrey, S.-i. Orimo, S. Jalisatgi and C. M. Jensen, Chem. Commun., 2011, 47, 1330.

10113 W. V. Hough and J. M. Makhlouf, U.S. Patent No. 3,313,603, 1967.

114 D. A. L. Carvalho and N. W. Shust, U.S. Patent No. 3,564,561, 1971.

115 Y. Deng, D. Zhao, Z. Shan, Z. Peng and J. Song, Chinese Patent No. CN85100253A, 1986.

116 Z. Huang, X. Chen, T. Yisgedu, E. A. Meyers, S. G. Shore and J. -C.

15 Zhao, Inorg. Chem., 2011, 50, 3738.

117 W. T. Klooster, T. F. Koetzle, P. E. M. Siegbahn, T. B. Richardson and R. H. Crabtree, J. Am. Chem. Soc., 1999, 121, 6337.

118 A. Brockman, Y. Zheng and J. Gore, Int. J. Hydrogen Energy, 2010, 35, 7350 .

20119 Rohm and Haas: The Sodium Borohydride Digest, 2003, 8.

120 B. H. Liu and Z. P. Li, J. Power Sources, 2009, 187, 527.

121 J. C. Walter, A. Zurawski, D. Montgomery, M. Thornburg and S. Revankar, J. Power Sources, 2008, 179, 335.

122 G. Kodama and R. W. Parry, J. Am. Chem. Soc., 1960, 82, 6250.

25123 S. G. Shore and H. D. Johnson II, J. Am. Chem. Soc., 1970, 92, 7586.

124 M. A. Toft, J. B. Leach, F. L. Himpsl and S. G. Shore, Inorg. Chem., 1982, 21, 1952.

125 Z. Huang, S. Porter, X. Chen, A. Du, H. K. Lingam, S. G. Shore and J.-C. Zhao, unpublished manuscript entitled: "Synthesis, structural

30 analysis, and thermal decomposition studies of $\left(\mathrm{NH}_{3}\right)_{2} \mathrm{BH}_{2} \mathrm{~B}_{3} \mathrm{H}_{8}$ ".

126 E. Mayer, Inorg. Chem., 1972, 11, 866.

127 S. G. Shore and R. W. Parry, J. Am. Chem. Soc., 1958, 80, 8.

128 D. Neiner, A. Karkamkar, M. Bowden, Y. J. Choi, A. Luedtke, J. Holladay, A. Fisher, N. Szymczak and T. Autrey, Energy Environ.

35 Sci., 2011, 4, 4187.

129 P. G. Campbell, L. N. Zakharov, D. J. Grant, D. A. Dixon and S. -Y. Liu, J. Am. Chem. Soc., 2010, 132, 3289.

130 A. N. Lamm, E. B. Garner, D. A. Dixon and S. -Y. Liu, Angew. Chem., Int. Ed., 2011, 50, 8157.

40131 W. Luo, L. N. Zakharov and S. -Y. Liu, J. Am. Chem. Soc., 2011, 133, 13006

132 W. Luo, P. G. Campbell, L. N. Zakharov and S. -Y. Liu, J. Am. Chem. Soc., 2011, 133, 19326.

133 G. C. Andrews, Tetrahedron Lett., 1980, 21, 697.

45134 B. L. Allwood, H. Shahriarizavareh, J. F. Stoddart and D. J. Williams, J. Chem. Soc., Chem. Commun., 1984, 22, 1461.

135 G. C. Andrews and T. C. Crawford, Tetrahedron Lett., 1980, 21, 693.

136 R. O. Hutchins, W. Y. Su, R. Sivakumar, F. Cistone and Y. P. Stercho, J. Org. Chem., 1983, 48, 3412.

50137 X. H. Yang, L. L. Zhao, T. Fox, Z. X. Wang and H. Berke, Angew. Chem., Int. Ed., 2010, 49, 2058.

138 A. P. M. Robertson, E. M. Leitao and I. Manners, J. Am. Chem. Soc., 2011, 133, 19322.

139 W. Xu , H. Fan, G. Wu and P. Chen, New J. Chem., 2012, 36, 1496.

55140 R. Angamuthu, P. Byers, M. Lutz, A. L. Spek and E. Bouwman, Science, 2010, 327, 313.

141 S. Sato, T. Morikawa, S. Saeki, T. Kajino and T. Motohiro, Angew. Chem., 2010, 122, 5227.

142 G. Ménard and D. W. Stephan, J. Am. Chem. Soc., 2010, 132, 1796.

60143 P. M. Zimmerman, Z. Zhang and C. B. Musgrave, Inorg. Chem., 2010, 49, 8724.

144 A. E. Ashley, A. L. Thompson and D. O’Hare, Angew. Chem. Int. Ed., 2009, 48, 9839.

145 G. C.Welch, R. R. S. Juan, J. D. Masuda, D. W. Stephan, Science

$65 \quad$ 2006, 314, 1124.

146 V. Sumerin, F. Schulz, M. Atsumi, C. Wang, M. Nieger, M. Leskela, T. Repo, P. Pyykko and B. Rieger, J. Am. Chem. Soc., 2008, 130, 14117.

147 D. W. Stephan, S. Greenberg, T. W. Graham, P. Chase, J. J. Hastie,

70 S. J. Geier, J. M. Farrell, C. C. Brown, Z. M. Heiden, G. C. Welch and M. Ullrich, Inorg. Chem., 2011, 40, 12338.
148 H. I. Schlesinger, D. M. Ritter and A. B. Burg, J. Am. Chem. Soc., 1938, 60, 2297.

149 K. J. Fijałkowski and W. Grochala, J. Mater. Chem., 2009, 19, 2043.

75150 U.S. DOE has complied a publically available, searchable database on hydrogen storage materials. http://hydrogenmaterialssearch.govtools.us/. 